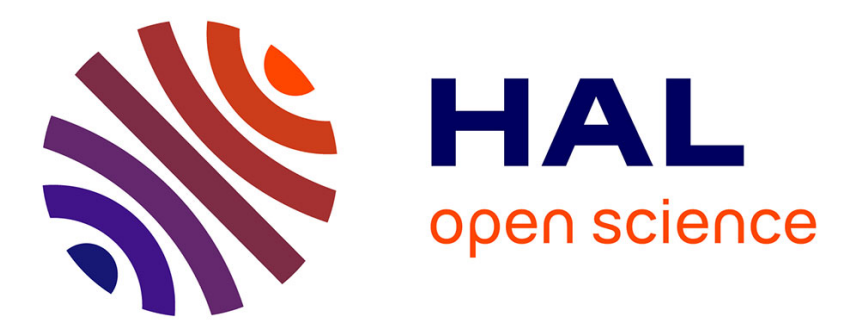

\title{
The type 1 cannabinoid receptor is highly expressed in embryonic cortical projection neurons and negatively regulates neurite growth in vitro
}

Tania Vitalis, Jeanne Lainé, Anne Simon, Alexandre B. Roland, Christophe Leterrier, Zsolt Lenkei

\section{To cite this version:}

Tania Vitalis, Jeanne Lainé, Anne Simon, Alexandre B. Roland, Christophe Leterrier, et al.. The type 1 cannabinoid receptor is highly expressed in embryonic cortical projection neurons and negatively regulates neurite growth in vitro. European Journal of Neuroscience, 2008, 28 (9), pp.1705-1718. 10.1111/j.1460-9568.2008.06484.x . hal-01701559

\section{HAL Id: hal-01701559 \\ https://hal.science/hal-01701559}

Submitted on 20 Apr 2018

HAL is a multi-disciplinary open access archive for the deposit and dissemination of scientific research documents, whether they are published or not. The documents may come from teaching and research institutions in France or abroad, or from public or private research centers.
L'archive ouverte pluridisciplinaire HAL, est destinée au dépôt et à la diffusion de documents scientifiques de niveau recherche, publiés ou non, émanant des établissements d'enseignement et de recherche français ou étrangers, des laboratoires publics ou privés. 


\title{
The type 1 cannabinoid receptor is highly expressed in embryonic cortical projection neurons and negatively regulates neurite growth in vitro
}

\author{
Tania Vitalis, ${ }^{1,2}$ Jeanne Lainé, ${ }^{3}$ Anne Simon, ${ }^{1}$ Alexandre Roland, ${ }^{1}$ Christophe Leterrier ${ }^{1, *}$ and Zsolt Lenkei ${ }^{1}$ \\ ${ }^{1}$ CNRS-UMR 7637, Laboratoire de neurobiologie et diversité cellulaire, 10 rue Vauquelin, ESPCI, 75005 Paris, France \\ ${ }^{2}$ INSERM U616, Hôpital de la Pitié-Salpétrière, Paris, France \\ ${ }^{3}$ Laboratoire de Neurobiologie du Cervelet, Université Pierre et Marie Curie Paris 6, Faculté de Médecine Pitié Salpétrière, Paris, \\ France
}

Keywords: axons, cerebral cortex, dendrites, differentiation, mouse, rat

\begin{abstract}
In the rodent and human embryonic brains, the cerebral cortex and hippocampus transiently express high levels of type 1 cannabinoid receptors $\left(\mathrm{CB}_{1} \mathrm{Rs}\right)$, at a developmental stage when these areas are composed mainly of glutamatergic neurons. However, the precise cellular and subcellular localization of $\mathrm{CB}_{1} \mathrm{R}$ expression as well as effects of $\mathrm{CB}_{1} \mathrm{R}$ modulation in this cell population remain largely unknown. We report that, starting from embryonic day $12.5, \mathrm{CB}_{1}$ Rs are strongly expressed in both reelinexpressing Cajal-Retzius cells and newly differentiated postmitotic glutamatergic neurons of the mouse telencephalon. $\mathrm{CB}_{1} \mathrm{R}$ protein is localized first to somato-dendritic endosomes and at later developmental stages it localizes mostly to developing axons. In young axons, $\mathrm{CB}_{1} \mathrm{Rs}$ are localized both to the axolemma and to large, often multivesicular endosomes. Acute maternal injection of agonist $\mathrm{CP}-55940$ results in the relocation of receptors from axons to somato-dendritic endosomes, indicating the functional competence of embryonic $\mathrm{CB}_{1} \mathrm{Rs}$. The adult phenotype of $\mathrm{CB}_{1} \mathrm{R}$ expression is established around postnatal day 5 . By using pharmacological and mutational modulation of $\mathrm{CB}_{1} R$ activity in isolated cultured rat hippocampal neurons, we also show that basal activation of $\mathrm{CB}_{1} R$ acts as a negative regulatory signal for dendritogenesis, dendritic and axonal outgrowth, and branching. Together, the overall negative regulatory role in neurite development suggests that embryonic $\mathrm{CB}_{1} \mathrm{R}$ signaling may participate in the correct establishment of neuronal connectivity and suggests a possible mechanism for the development of reported glutamatergic dysfunction in the offspring following maternal cannabis consumption.
\end{abstract}

\section{Introduction}

Marijuana is the most widely used illicit drug among women of reproductive age (Fried \& Smith, 2001; Ebrahim \& Gfroerer, 2003). $\Delta^{9}$-tetrahydrocannabinol, the major psychoactive substance of marijuana and hashish, readily crosses the placental barrier (Hutchings et al., 1989) and prenatal marijuana exposure has been shown to result in negative neurobehavioral consequences in the offspring (reviewed by Fried \& Smith, 2001). Accordingly, it has been shown that prenatal cannabinoid exposure transiently or permanently alters the function of GABAergic (Garcia-Gil et al., 1999; Berghuis et al., 2007), dopaminergic (Walters \& Carr, 1986, 1988; Rodriguez de Fonseca et al., 1991; Bonnin et al., 1995, 1996), serotoninergic (Molina-Holgado et al., 1996) and opioidergic (Vela et al., 1998) neuronal systems. Specifically, several aspects of executive function appear to be

Correspondence: Dr Z. Lenkei and Dr T. Vitalis, as above.

E-mail: zsolt.lenkei@espci.fr and tmvitalis@hotmail.com

* Present address: INSERM U641, Université de la Méditerranée, Faculté de Médecine Secteur-Nord, IFR 11, Marseille, F-13916 France.

Received 9 June 2008, revised 28 August 2008, accepted 4 September 2008 negatively associated with in-utero cannabis exposure. Clinical and empirical evidence indicates that executive functions are primarily subserved by the prefrontal region of the brain but may also involve other structures such as the hippocampus (Barch, 2005). The predominant neuronal type of cortical structures are glutamatergic neurons and it has been demonstrated that prenatal cannabinoid exposure is also associated with changes in glutamate transmission in the offspring (Mereu et al., 2003; Antonelli et al., 2004, 2005; Castaldo et al., 2007). Although functionally important type 1 cannabinoid receptors $\left(\mathrm{CB}_{1} \mathrm{Rs}\right)$ are also expressed, albeit at relatively low levels, in adult glutamatergic axon terminals (Katona et al., 2006; Kawamura et al., 2006), a strikingly strong and transient elevation of $\mathrm{CB}_{1} \mathrm{R}$ binding and mRNA expression was described in the cerebral cortex at developmental stages when this structure is almost entirely composed of developing glutamatergic neurons (reviewed in Fernandez-Ruiz et al., 1999). However, the resolution of these pioneering studies was not sufficient to identify the $\mathrm{CB}_{1} \mathrm{R}$-expressing cells. Importantly, white matter areas containing the developing axons of glutamatergic neurons also showed strong and transient expression of functional $\mathrm{CB}_{1} \mathrm{R}$, first detected by binding of labeled cannabinoid 
ligands and by agonist-induced GTP $\gamma \mathrm{S}$ binding (Fernandez-Ruiz et al., 1999). Axonal expression was recently confirmed by immunohistochemistry (Berghuis et al., 2007) but precise spatio-temporal patterns of $\mathrm{CB}_{1} \mathrm{R}$ expression in young telencephalic glutamatergic neurons remain largely unknown. Subcellular distribution, which is strongly related to $\mathrm{CB}_{1} \mathrm{R}$ activation levels (Leterrier et al., 2004, 2006), is also unknown for $\mathrm{CB}_{1} \mathrm{Rs}$ as well as for the majority of embryonic G-protein-coupled receptors.

In the present study, using optical and electron microscopy, we first describe, at high resolution, $\mathrm{CB}_{1} \mathrm{R}$ localization in the cerebral cortex and hippocampus from embryonic day (E)12.5 to postnatal day (P)5. Next, by using pharmacological and mutational modulation of $\mathrm{CB}_{1} \mathrm{R}$ activity in isolated cultured hippocampal neurons, we show that the modification of $\mathrm{CB}_{1} \mathrm{R}$ activation significantly modulates outgrowth of dendrites and axons. Our results suggest that embryonic $\mathrm{CB}_{1} \mathrm{R}$ signaling participates in the correct establishment of neuronal connectivity and propose a possible mechanism for the development of reported glutamatergic dysfunction in the offspring following maternal cannabis consumption. A part of these results was previously reported as a conference poster (Vitalis et al., 2004).

\section{Materials and methods}

\section{Animals}

Animal procedures were conducted in strict compliance with approved institutional protocols and in accordance with the provisions for animal care and use described in the European Communities council directive of November 24, 1986 (86/609/EEC). Sprague-Dawley rats (Janvier) were used for dissociated cell culture experiments. Mice (OF1 or C57/B16 strains) were purchased from Charles River. Animals expressing green fluorescent protein (GFP) under the control of the $5-\mathrm{HT}_{3 \mathrm{~A}}$ promoter $\left(5-\mathrm{HT}_{3 \mathrm{~A}}: \mathrm{GFP}\right)$ were purchased from The Gene Expression Nervous System Atlas Project (Rockefeller University, New York, NY, USA) and were obtained by homologous recombination of a bacterial artificial chromosome containing the 5$\mathrm{HT}_{3 \mathrm{~A}}$ gene that will be fully described elsewhere (Ksenija Vucurovic and Tania Vitalis, unpublished observation). Genitors were phenotyped using UV illumination. The day of vaginal plug detection was counted as E0.5 for the mice and E0 for the rats.

\section{Reagents}

Mouse monoclonal antibodies raised against reelin (G10, $1: 500$, a kind gift of Dr Goffinet, Université Catholique de Louvain), neuronspecific beta III tubulin (Tuj-1) $(1: 2000$, Berkeley Antibody Company, Richmond, CA, USA), the $67 \mathrm{kDa}$ isoform of glutamic acid decarboxylase (1 : 5000, MAB5406, Chemicon International), microtubule-associated protein 2 (clone HM-2, Sigma, St Louis, MO, USA) and the FLAG epitope (clone M1, Sigma) were used. Rabbit polyclonal antibody raised against the $\mathrm{C}$-terminal portion of the $\mathrm{CB}_{1}$ receptor (C-Ter; $1: 200$ for embryonic tissue and 1:1000 for culture experiments) was produced by Eurogentec (Seraing, Belgium) and has been characterized previously (Leterrier et al., 2004). Alexa-Fluorconjugated $(1: 400-1: 600)$ secondary antibodies were from Invitrogen. DsRed2 encoding plasmid was from Clontech (Mountain View, $\mathrm{CA}$, USA). Our validated $\mathrm{CB}_{1}$-enhanced green fluorescent protein (EGFP) and FLAG-CB 1 -EGFP constructs were used as previously described (Leterrier et al., 2004, 2006). Mutants displaying either enhanced agonist affinity (T210I) or enhanced inverse agonist affinity (T210A) relative to the wild-type constructs (D'Antona et al., 2006) were obtained using Quikchange mutagenesis (Stratagene) of the FLAG-CB ${ }_{1}$-EGFP plasmid. The following chemicals were used for pharmacological treatments: $\mathrm{CB}_{1} \mathrm{R}$ agonists CP-55940 (Tocris, Bristol, UK) and (R)-(-)-[2,3-dihydro-5-methyl-3-(4-morpholinylmethyl)pyrrolo[1,2,3-de]-1,4-benzoxazin-6-yl]-1-naphthalenyl-methanone mesylate [WIN55,212-2 (WIN); Sigma], and $\mathrm{CB}_{1} \mathrm{R}$ inverse agonist 1-(2,4-dichlorophenyl)-5-(4-iodophenyl)-4-methyl- $N$-4-morpholinyl-1H-pyrazole-3-carboxamide (AM281, Tocris). All culture media and additives were from Invitrogen.

\section{Acute treatments of pregnant dams}

Pregnant dams bearing E16.5 embryos received a single injection of the $\mathrm{CB}_{1} \mathrm{R}$ agonist CP-55940 (0.7 mg/kg, i.p.; Sigma) or vehicle 2 and/or $12 \mathrm{~h}$ before killing. Embryos were dissected out in cold phosphate buffer $(0.1 \mathrm{M})$ and were immersed overnight in $4 \%$ paraformaldehyde in $0.1 \mathrm{M}$ phosphate buffer, $\mathrm{pH}$ 7.4.

\section{Radioactive in-situ hybridization}

The $\mathrm{CB}_{1} \mathrm{R}$ cRNA probe (a kind gift of Dr Beat Lutz, Johannes Gutenberg University, Mainz) corresponded to the full-length protein. The plasmid was linearized with BamH1 for antisense RNA synthesis by T7 polymerase and with EcoRI for sense RNA synthesis by T3 polymerase. The transcription was carried out using the Promega kit and probes were labeled with ${ }^{35} \mathrm{~S}-\mathrm{UTP}$ ( $>1000 \mathrm{Ci} / \mathrm{mmol}$; Amersham). Hybridization was performed on fresh frozen brain sections (15 $\mu \mathrm{m}$ thick) as described in Fontaine \& Changeux (1989). Slides were dipped in photographic emulsion (NTB2, Kodak). After 5-10 days the emulsion was developed and sections were Nisslstained $(0.25 \%$ thionin solution).

\section{Immunohistochemistry on brain sections}

In order to analyse expression of the $\mathrm{CB}_{1} \mathrm{R}$ protein, brains were obtained at embryonic (E12.5, E14.5 and E16.5) and postnatal (P0 and P5) stages. Embryos were placed overnight in 4\% paraformaldehyde in $0.1 \mathrm{M}$ phosphate buffer, $\mathrm{pH} 7.4$, then cryoprotected, embedded into gelatine $(7 \%)$ /sucrose $(10 \%)$, frozen into isopentane $\left(-40^{\circ} \mathrm{C}\right)$ and stored at $-80^{\circ} \mathrm{C}$ until processing. Postnatal animals were deeply anesthetized with intraperitoneal pentobarbital injection $(150 \mathrm{mg} / \mathrm{kg}$ body weight) and perfused transcardially with $4 \%$ paraformaldehyde. Brains were processed as described above. Blocks were sectioned coronally with a cryostat $(20 \mu \mathrm{m}$ thick). Sections were incubated overnight at $4{ }^{\circ} \mathrm{C}$ with the primary antibodies, washed and incubated with Alexa 568-conjugated goat anti-rabbit and/or Alexa 488conjugated anti-mouse antibodies $(1: 200)$. Sections were finally mounted in Vectashield (Vector, CA, USA) containing 4'6-diamidino2-phenylindole $2 \mathrm{HCl}$ (DAPI) (1: 1000).

After fixation, for the analysis of the effects of chronic treatments, brains were embedded in $0.1 \mathrm{M}$ phosphate buffer/agarose $(3 \%), \mathrm{pH}$ 7.4 , and sectioned with a vibratome $(45 \mu \mathrm{m})$. Sections were permeabilized and incubated overnight at $4{ }^{\circ} \mathrm{C}$ with the primary antibodies, then washed and incubated with secondary antibodies. Sections were washed, nuclei were labeled with bisbenzimide $(1 \mu \mathrm{g} / \mathrm{mL})$ and sections were finally mounted in Vectashield (Vector).

\section{Ultrastructural pre-embedding immunocytochemistry}

Embryonic mouse brains obtained from untreated or treated dams (see above) were quickly dissected as described above and immediately 
fixed by immersion in either $4 \%$ paraformaldehyde with $0.1 \%$ glutaraldehyde in $0.1 \mathrm{M}$ phosphate buffer or $2 \%$ paraformaldehyde plus $1 \%$ glutaraldehyde, first for $1 \mathrm{~h}$ at room temperature $\left(23^{\circ} \mathrm{C}\right)$ and then overnight at $4^{\circ} \mathrm{C}$. Brains were then embedded in $3 \%$ agarose, cut with a vibratome and $150-\mu \mathrm{m}$-thick coronal sections were collected. Two aldehyde quenching steps in $0.1 \%$ sodium borohydrate and $0.1 \mathrm{M}$ glycine preceded the blocking step of non-specific sites in 5\% normal goat serum $+5 \%$ bovine serum albumin. An overnight incubation at room temperature was performed in anti- $\mathrm{CB}_{1} \mathrm{R}(1: 500$ in phosphatebuffered saline). For immunoperoxidase procedures, a biotinylated anti-rabbit IgG (Vector) was applied as secondary antibody (1:200 in phosphate-buffered saline, $2 \mathrm{~h}$ ) and the $\mathrm{ABC}$ peroxidase complex (Vectastain Elite, Vector) was used for amplification. Revelation was performed with $0.05 \%$ diaminobenzidin as the chromogen. For immunogold labelings, a $5 \mathrm{~h}$ incubation in ultra-small gold conjugate $\left.\mathrm{F}(\mathrm{ab})^{2}\right)^{2}$ fragments of goat anti-rabbit IgG (1 : 200; Aurion, Netherlands) was followed by extensive washing, 10 min postfixation in $2 \%$ glutaraldehyde and a silver enhancement reaction (R-Gent SE-ME kit, Aurion). Some sections were submitted to a gold-toning procedure to protect silver deposits from osmium displacement. After $\mathrm{OsO}_{4}$ postfixation ( $2 \%$ for immunoperoxidase labeling and $1 \%$ for gold revelation) and $2 \%$ uranyl acetate en-bloc staining, immunostained sections were dehydrated in graded acetone and finally embedded in Durcupan (Fluka, Switzerland) resin. Observations were made with a Phillips CM120 electron microscope and digitalized with a Morada camera.

\section{Hippocampal neuronal cultures}

Hippocampal neuronal cultures were performed essentially as described by Goslin \& Banker (1989) with some modifications (Jolimay et al., 2000). Briefly, hippocampi of rat embryos were dissected at E17. After trypsinization, dissociation was achieved with a fire-polished Pasteur pipette. Cells were counted and plated on polyD-lysine-coated (Sigma) 15-mm-diameter glass coverslips at a density of $400-500$ cells $/ \mathrm{mm}^{2}$. The plating medium was Neurobasal supplemented with 2\% B27 and containing Glutamax I (0.5 mM) and penicillin $\mathrm{G}(10 \mathrm{U} / \mathrm{mL}) /$ streptomycin $(10 \mathrm{~g} / \mathrm{mL})$. At $4 \mathrm{~h}$ after plating, the coverslips were transferred into Petri dishes containing supplemented Neurobasal medium that was conditioned for $24 \mathrm{~h}$ on an $80 \%$ confluent glial layer. Neurons were transfected after 3 days in vitro (DIV) using Lipofectamine 2000 (Invitrogen), following the manufacturer's instructions. They were treated and processed at 1 DIV after transfection. For pharmacological treatments, ligands dissolved in dimethylsulfoxide were added directly to the culture medium. The highest final concentration reached was $0.2 \%$ dimethylsulfoxide; control experiments with up to $0.5 \%$ dimethylsulfoxide have shown the absence of effects on neuronal morphology and on the cellular distribution of $\mathrm{CB}_{1} \mathrm{Rs}$ (data not shown).

\section{Immunocytochemistry on cultured neurons}

For immunocytochemistry, neurons were briefly rinsed with Dulbecco's phosphate-buffered saline (DPBS) (Invitrogen) and fixed in DPBS containing $4 \%$ paraformaldehyde and $4 \%$ sucrose. After permeabilization with $5 \mathrm{~min}$ incubation in DPBS containing $0.1 \%$ Triton X-100 and blocking for $30 \mathrm{~min}$ in antibody buffer (DPBS supplemented with $2 \%$ bovine serum albumin and $3 \%$ normal goat serum), neurons were incubated with primary antibodies diluted $1: 500-1: 5000$ in antibody buffer for $1-2 \mathrm{~h}$ at room temperature. After DPBS rinses, neurons were labeled with secondary antibodies diluted to $1: 400$ in antibody buffer for $1 \mathrm{~h}$ at room temperature. Coverslips were finally mounted in Mowiol (Calbiochem, La Jolla, CA, USA) eventually containing Hoechst 33432 diluted to $1: 1000$.

\section{Microscopy and morphometry}

Wide-field images were taken on a Leica DM-R microscope using a dry 20×, NA 0.7 objective and QImaging (Burnaby, British Columbia, Canada) QICAM. In all cases, emission and excitation filters proper to each fluorophore were used sequentially and the absence of cross-talk between different channels was checked with selectively labeled preparations. Neurites were outlined and measured using an assisted semiautomatic method (NeuronJ) (Meijering et al., 2004). For neurons at DIV3, axon, primary and secondary dendrites were outlined and measured for their number and length. For neurons at DIV10, IMAGEJ (http://rsb.info.nih.gov/ij/index.html) was used to delete the somatodendritic area and the function 'skeletonize' was used to reduce all axonal arborescence to a single pixel network. Pixels were then counted to estimate the extent of the axonal network. All measurements were analysed and plotted using the PRISM software (GraphPad, San Diego, CA, USA). Significance of differences between various conditions was calculated using one-way ANOVA with Newman-Keuls post-tests for computing $\mathrm{p}$ estimates.

\section{Results \\ $C B_{1} R$ expression in the developing cortico-hippocampal formation}

First, by using in-situ hybridization, confocal microscopy and electron microscopy, we determined the precise cellular distribution of $\mathrm{CB}_{1} \mathrm{Rs}$ in the developing cerebral cortex and hippocampus from E12.5 until birth. Between E12.5 and E13.5 $\mathrm{CB}_{1} \mathrm{R}$ mRNA and protein were expressed by a large proportion of newly differentiated neurons of the cortical preplate as indicated by the co-expression of $\mathrm{CB}_{1} \mathrm{R}$ with the neuron-specific and early-differentiation marker class III beta-tubulin (Tuj-1) (Menezes \& Luskin, 1994) (Fig. 1A1-A3 and C). We have not observed significant $\mathrm{CB}_{1} \mathrm{R}$ protein or mRNA expression in the ventricular zone. In the preplate, $\mathrm{CB}_{1} \mathrm{R}$ was expressed by a subpopulation of reelin-expressing Cajal-Retzius pioneer neurons (G10-positive cells in Fig. 1D1-D3). Both soma and growing neuritic processes were decorated by a punctuated intracellular $\mathrm{CB}_{1} \mathrm{R}$ immunolabeling (Fig. 1C, see also Supporting information, Fig. S1 and Video S1). Electron microscopic analysis showed that this punctuate labeling corresponded to $\mathrm{CB}_{1}$ Rs that were exclusively associated with the external membrane of large electrolucent endosomes (200$400 \mathrm{~nm}$ ) (Fig. 1E-H).

By E14.5, $\mathrm{CB}_{1} \mathrm{R}$ mRNA was still strongly expressed in the entire cortical plate (data not shown). Immunohistochemistry showed that the major proportion of $\mathrm{CB}_{1} \mathrm{R}$ protein was gradually relocalized into growing axons of maturing projection neurons (Fig. 2A). Thus, in the more mature lateral parts of cerebral cortex, $\mathrm{CB}_{1} \mathrm{R}$ immunolabeling was mainly localized in the intermediate zone, where Tuj-1-positive (Fig. 2B1-B3) corticofugal axons are located (Del Río et al., 2000). At the same time, in the less mature medial parts of the cortical region, which will later give rise to the hippocampus, punctuate $\mathrm{CB}_{1} \mathrm{R}$ immunolabeling was localized to somatic endosomes of newly differentiated neurons that did not yet show axonal processes. Thus, electron microscopy indicated that, in the medial part of the cortex, $\mathrm{CB}_{1} \mathrm{R}$ immunolabeling was associated with large and complex endosomes in the soma (Fig. 2C and D), similar to the distribution observed at E12.5, as shown in Fig. 1. In the axonal compartment, 

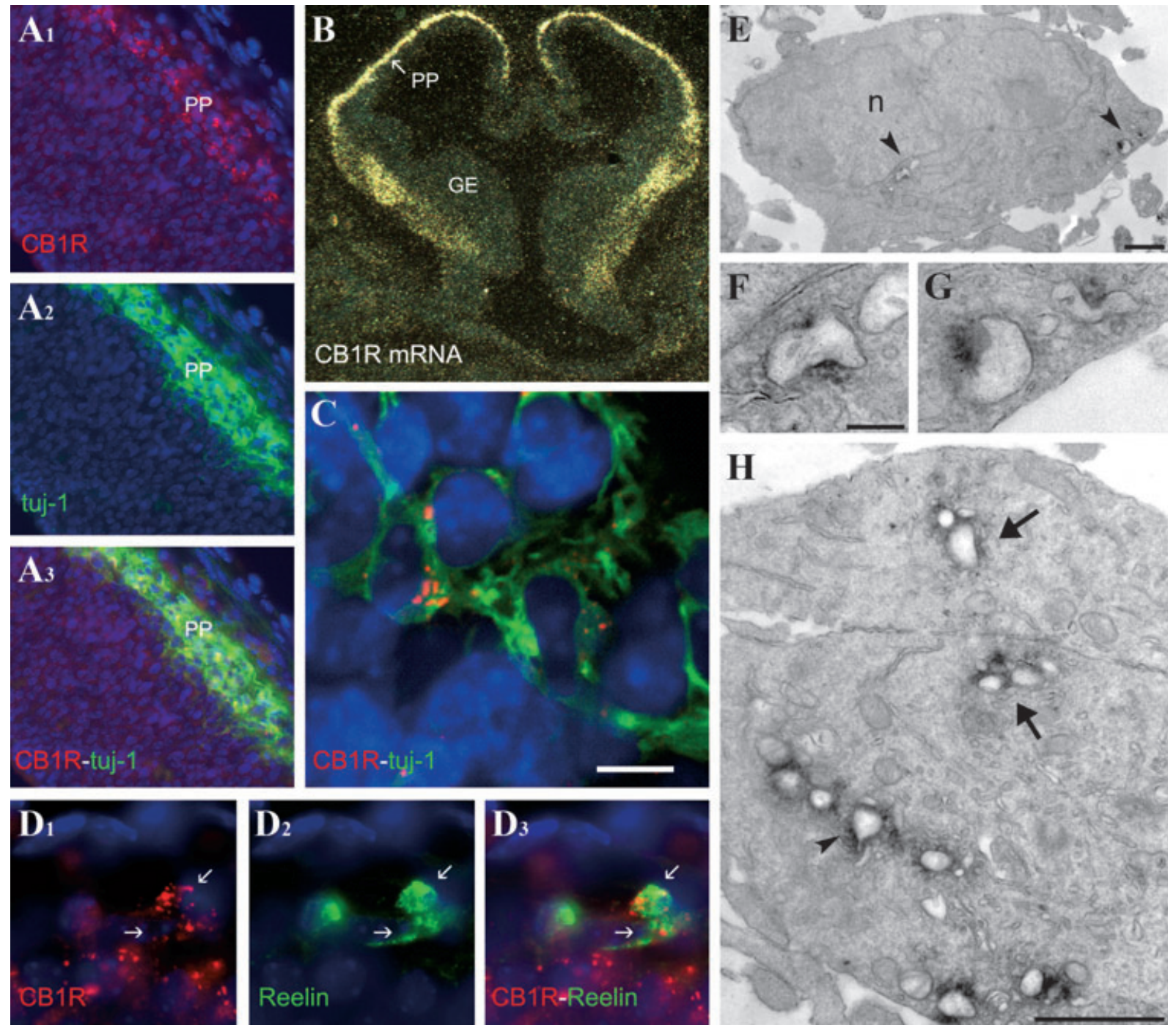

FIG. 1. Localization of $\mathrm{CB}_{1} \mathrm{R}$ in cortical neurons at E12.5. (A1-A3) Immunolabeling of $\mathrm{CB}_{1} \mathrm{R}(\mathrm{A} 1$; red) in Tuj-1-positive neurons (A2; green) of the preplate (PP). Sections are counterstained with DAPI (blue). (B) In-situ hybridization showing $\mathrm{CB}_{1} \mathrm{R}$ mRNA in the telencephalon. Note the absence of $\mathrm{CB}_{1} \mathrm{R}$ mRNA in the ganglionic eminence (GE). (C) Confocal view showing punctiform $\mathrm{CB}_{1} \mathrm{R}$ labeling in the somata and neurites of preplate cells. See also supporting Video S1. (D1D3) Co-localization of $\mathrm{CB}_{1} \mathrm{R}$ (red) with reelin (green) in the cortical marginal zone (arrows). (E-H) Ultrastructural $\mathrm{CB}_{1} \mathrm{R}$ immunoperoxidase labeling of preplate cortical neurons. Please note that the dissociated aspect of neurons is an artifact of the electron microscopic procedure, due to the fragility of embryonic brain tissue at this early stage. (E) Neuronal soma with an indentated nucleus (n). Arrowheads point to three $\mathrm{CB}_{1}$ R-labeled endosomes that are enlarged in F and G. (F and G) Note that $\mathrm{CB}_{1} \mathrm{R}$ immunoprecipitate is localized on the cytoplasmic side of the limiting membrane of large endosomes. Their lumen is electrolucent and contains membranous or more frequently 'dusty' debris. (H) Soma profiles of two contiguous preplate neurons containing numerous $\mathrm{CB}_{1} \mathrm{R}$-positive large endosomes. These are rather circular in shape and some appear to correspond to fusioning endosomes (arrows). The arrowhead indicates an endosome with a tubular extension. Bar in $\mathrm{C}=150 \mu \mathrm{m}$ for $\mathrm{A} 1-\mathrm{A} 3,1.25 \mathrm{~mm}$ for B, $20 \mu \mathrm{m}$ for D1-D3 and $8 \mu \mathrm{m}$ for C. Bars in E and $\mathrm{H}=1 \mu \mathrm{m}$. Bar in F (same for G) $=0.2 \mu \mathrm{m}$.

$\mathrm{CB}_{1} \mathrm{R}$ immunolabeling was associated with the plasma membrane (Fig. 2E and G), accompanied by labeling of the outer membrane of small clear lumen vesicles (Fig. 2F, H and I). However, as the diaminobenzidin precipitate used to reveal immunolabeling in this experiment may also result in artifactual labeling of membranes, we have also performed immunogold detection of $C_{1} R$. The resulting localization of gold beads confirmed that $\mathrm{CB}_{1} \mathrm{Rs}$ were localized to small clear lumen vesicles and were also more or less regularly disposed along the axonal plasma membrane (Fig. 2E). Finally, between E12.5 and E14.5, $\mathrm{CB}_{1} \mathrm{R}$ immunolabeling was absent from the ganglionic eminences where most cortical GABAergic neurons are generated (Fig. 2A)

By E16.5, $\mathrm{CB}_{1} \mathrm{R}$ mRNA was strongly expressed in the entire cortical plate and hippocampus (Fig. 3A), which are mainly composed of the perikarya of glutamatergic projection neurons at this stage (Rakic, 2006). Interestingly, the localization of $\mathrm{CB}_{1} \mathrm{R}$ protein was almost completely segregated from the localization of $\mathrm{CB}_{1} \mathrm{R}$ mRNA, with the protein being translocated to developing fiber tracts such as the fornix, anterior commissure, hippocampal commissure, fimbria hippocampi, corpus callosum and individual corticofugal axons ouside the above fiber tracts (Fig. 3B and C). At this stage, in the somato-dendritic compartment, the remaining $\mathrm{CB}_{1} \mathrm{R}$ immunolabeling was associated with the external surface of large endosomes similar to those described at earlier stages. In the axonal compartment (Fig. 3E), $\mathrm{CB}_{1} \mathrm{R}$ labeling was associated with intraaxonal endosomal organelles including multivesicular bodies (Fig. $3 \mathrm{G}$ and $\mathrm{H}$ ) and with the surface of the axons (Fig. 3F). At this stage, $\mathrm{CB}_{1} \mathrm{R}$ immunolabeling was not detected in the 

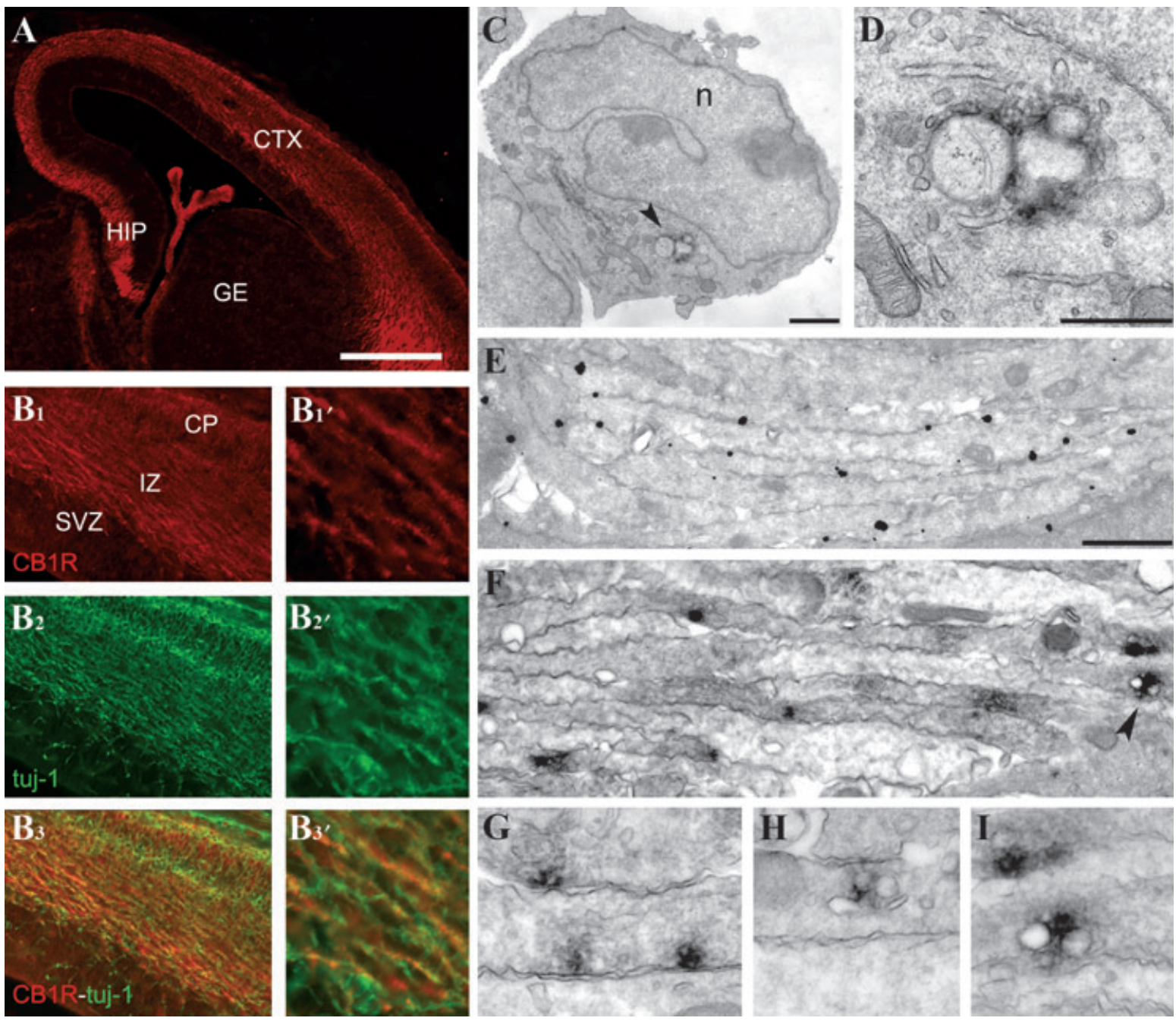

FIG. 2. Localization of $\mathrm{CB}_{1}$ Rs on projection neurons at E14.5. (A) Coronal section showing immunolabeling of $\mathrm{CB}_{1} \mathrm{R}$ in the cortex (CTX) and hippocampus (HIP). Note the lack of immunolabeling in the ganglionic eminence (GE). (B1-B3) Co-localization of $\mathrm{CB}_{1} \mathrm{R}$ (red) with Tuj-1 (green) in corticofugal axons in the intermediate zone (IZ). (B1'-B3') Higher magnification of B1-B3. Note that all $\mathrm{CB}_{1} \mathrm{R}$-positive fibers express Tuj-1. (C and D) Subcellular distribution of $\mathrm{CB}_{1} \mathrm{R}$ immunolabeling in neuronal somata. $(\mathrm{C})$ Representative example of $\mathrm{CB}_{1} \mathrm{R}$-positive cortical plate neuron with a deeply indentated nucleus $(\mathrm{n})$. $\mathrm{CB}_{1} \mathrm{R}$ labels a group of three connected round endosomes (arrowhead), further enlarged in $\mathrm{D}$. Note that $\mathrm{CB}_{1} \mathrm{R}$ precipitate remains restricted to the endosomal limiting membrane. (E-I) Subcellular distribution of $\mathrm{CB}_{1} \mathrm{R}$ immunoreactivity in corticofugal axons. (E) The majority of $\mathrm{CB}_{1} \mathrm{R}$-labeling gold beads are attached to the axonal membrane. (F) Scattered distribution of $\mathrm{CB}_{1} \mathrm{R}$ immunoprecipitate, either localized at the axolemma or, less frequently, within the axoplasma where it is usually found close to the outer membrane of small clear lumen vesicles (arrowhead, enlarged view in I). (G) High magnification of axolemma labeling. $(\mathrm{H}$ and $\mathrm{I}) \mathrm{CB}_{1} \mathrm{R}$-positive round vesicles. Bar in $\mathrm{A}=600 \mu \mathrm{m}$ for $\mathrm{A}, 250 \mu \mathrm{m}$ for B1-B3 and $80 \mu \mathrm{m}$ for B1' $-\mathrm{B} 3^{\prime}$. Bars in $\mathrm{C}$ and $\mathrm{E}$ (same for $\mathrm{F}$ ) $=1 \mu \mathrm{m}$. Bar in $\mathrm{D}=0.5 \mu \mathrm{m}$ and is also for G-I. CP, cortical plate; SVZ, subventricular zone.

subventricular zone where most GABAergic neurons are tangentially migrating (data not shown).

In order to investigate if $\mathrm{CB}_{1} \mathrm{R}$ proteins abundantly expressed in embryonic fiber tracts are functionally competent, we took advantage of the fact that, in neurons, agonist-mediated activation of functional G-protein-coupled receptors and more specifically of $\mathrm{CB}_{1} \mathrm{R}$ receptors ultimately results in internalization and retrograde somato-dendritic translocation (Coutts et al., 2001; Leterrier et al., 2004, 2006). Agonist-induced internalization is an event far downstream of G-protein-coupled receptor activation, which requires pharmacologically accessible receptors in a functionally relevant context allowing an appropriate ligand-mediated conformation change. Subsequent phosphorylation of specific threonine and serine residues leads to uncoupling of G-proteins and is followed by interaction with a cascade of scaffolding proteins (such as arrestins and chlatrin) that ultimately results in endocytosis and intracellular translocation (Hanyaloglu \& von Zastrow, 2008). Thus, agonist-induced internalization is a strong indication that the investigated G-protein-coupled receptor is indeed functionally competent. Cannabinoid analogs such as $\Delta^{9}$-tetrahydrocannabinol readily cross the placental barrier (Hutchings et al., 1989) and thus we expected that systemic treatment of pregnant dams with cannabinoid agonist would result in internalization of functional $\mathrm{CB}_{1} \mathrm{Rs}$ in the embryonic brain. Indeed, subacute intraperitoneal treatment of pregnant dams (two injections at 12 and $2 \mathrm{~h}$ before killing) at E16.5 with the $\mathrm{CB}_{1} \mathrm{R}$ agonist $\mathrm{CP}-55940$ resulted in a striking redistribution of $\mathrm{CB}_{1} \mathrm{Rs}$ toward the somato-dendritic compartments of projection neurons. Thus, in CP-55940-treated animals, only residual $\mathrm{CB}_{1} \mathrm{R}$ immunostaining could be observed in the hippocampal fimbria, and hippocampal projection neuron perikarya were decorated by a punctuated $\mathrm{CB}_{1} \mathrm{R}$ immunolabeling (Fig. 3D). We have observed a similar redistribution in the neocortex (data not shown). A single injection of CP-55940 (2 h before killing) led to a 

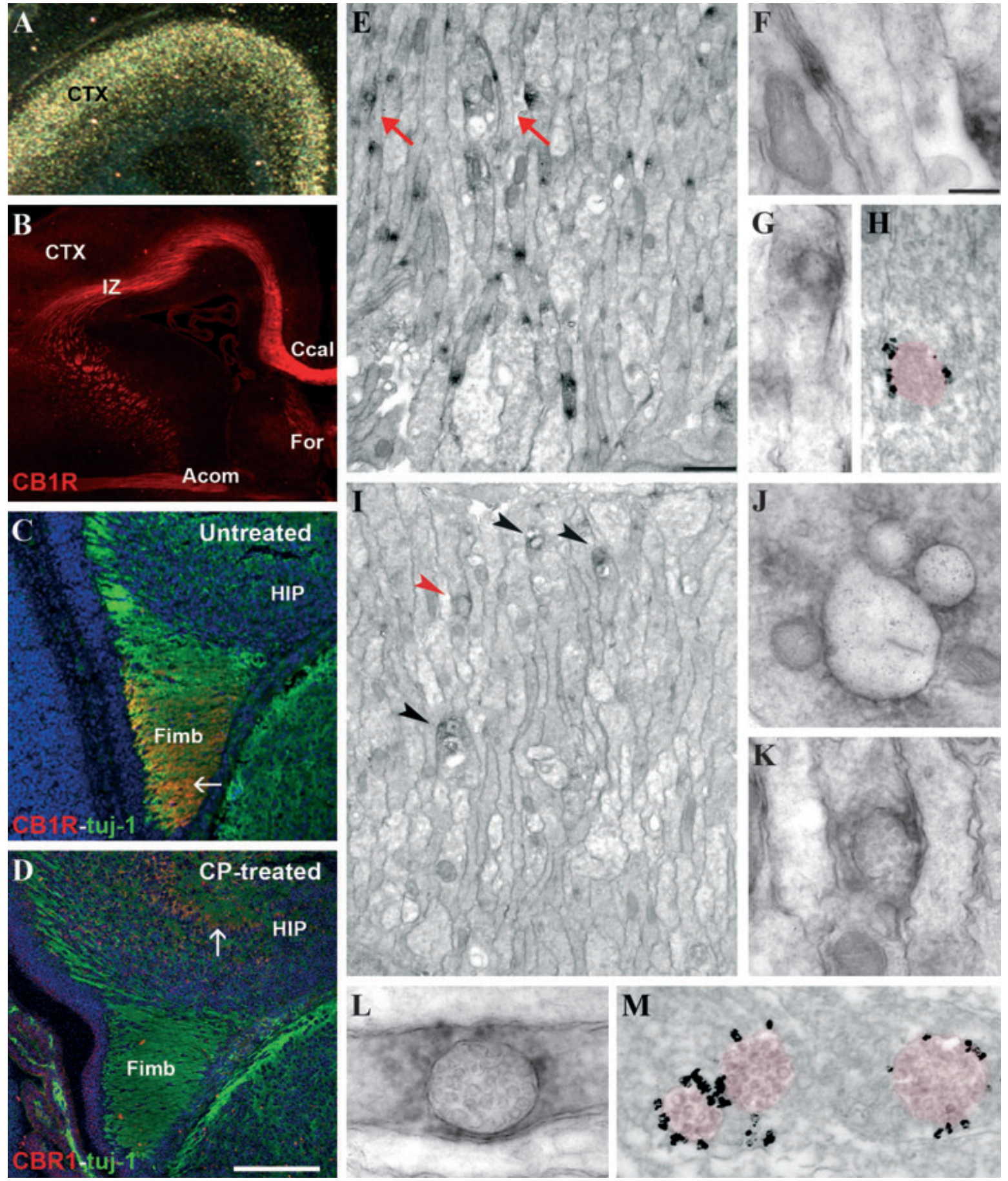

FIG. 3. Localization of $\mathrm{CB}_{1} \mathrm{Rs}$ at E16.5 is modified by treatment with $\mathrm{CB}_{1} \mathrm{R}$ agonist. (A) In-situ hybridization showing a high level of $\mathrm{CB}_{1} \mathrm{R}$ mRNA expression in the cortex (CTX). (B) Coronal section showing $\mathrm{CB}_{1} \mathrm{R}$ immunolabeling mainly restricted to axonal tracts, such as the intermediate zone (IZ), corpus callosum (Ccal), anterior commissure (Acom) and fornix (For). Maternal treatment with the $\mathrm{CB}_{1} \mathrm{R}$ agonist $\mathrm{CP}-55940$ (CP) (D) induces modification in the location of $\mathrm{CB}_{1} \mathrm{R}$ immunolabeling (red) in comparison with control condition (C). Axonal tracts are labeled with Tuj-1 (green) and sections are counterstained with DAPI (blue). (C) In the control condition, $\mathrm{CB}_{1} \mathrm{R}$ (red) is exclusively located in the fimbria (Fimb). (D) Following CP-55940 treatment $\mathrm{CB}_{1} \mathrm{R}$ is translocated to the somatic compartment of hippocampal neurons. Ultrastructural $\mathrm{CB}_{1} \mathrm{R}$ labeling of corticofugal axonal tracts in control embryonic brain (E-H) vs. $\mathrm{CB}_{1} \mathrm{R}$ agonist-treated embryos (I-M). (E) Corticofugal axon in a control embryo. Scattered $\mathrm{CB}_{1} \mathrm{R}$ precipitates label either the axonal membrane or intra-axonal endosomal organelles. Red arrows point to two areas enlarged in F and G. (F) Axolemma labeling. (G) $\mathrm{CB}_{1} \mathrm{R}$ labels the limiting membrane of a round endosome with an electrolucent lumen. (H) Immunogold labeling of the limiting membrane of an intra-axonal multivesicular endosome (light red mask for clarity), the other type of $\mathrm{CB}_{1} \mathrm{R}$-positive endosome found along axons. (I-M) Corticofugal axon labeling following CP-55940 administration. (I) Compared with control, labeling of the axolemma is reduced and immunopositivity is mostly found on organelles within the axonal lumen (arrowheads), most of them being multivesicular endosomes. These are more numerous and usually larger than in control axons. (J) Connected endosomes suggesting fusion events from the soma of a neocortical neuron. (K) Enlarged view of the multivesicular endosome indicated with the red arrowhead in I. (L) Another immunoperoxidase-labeled multivesicular body whose diameter nearly equals that of the axon. (M) Three multivesicular bodies aligned in a single axonal shaft and surrounded by gold beads. These results are representative for two independent experiments. Bar in $\mathrm{D}=625 \mu \mathrm{m}$ for $\mathrm{A}, 700 \mu \mathrm{m}$ for B, $300 \mu \mathrm{m}$ for $\mathrm{C}$ and $\mathrm{D}$. Bar in $\mathrm{E}$ (also for $\mathrm{I}$ ) $=1 \mu \mathrm{m}$. Bar in $\mathrm{F}$ (also for $\mathrm{G}, \mathrm{H}$ and $\mathrm{J}-\mathrm{M}$ ) $=0.2 \mu \mathrm{m}$. HIP, hippocampus. 

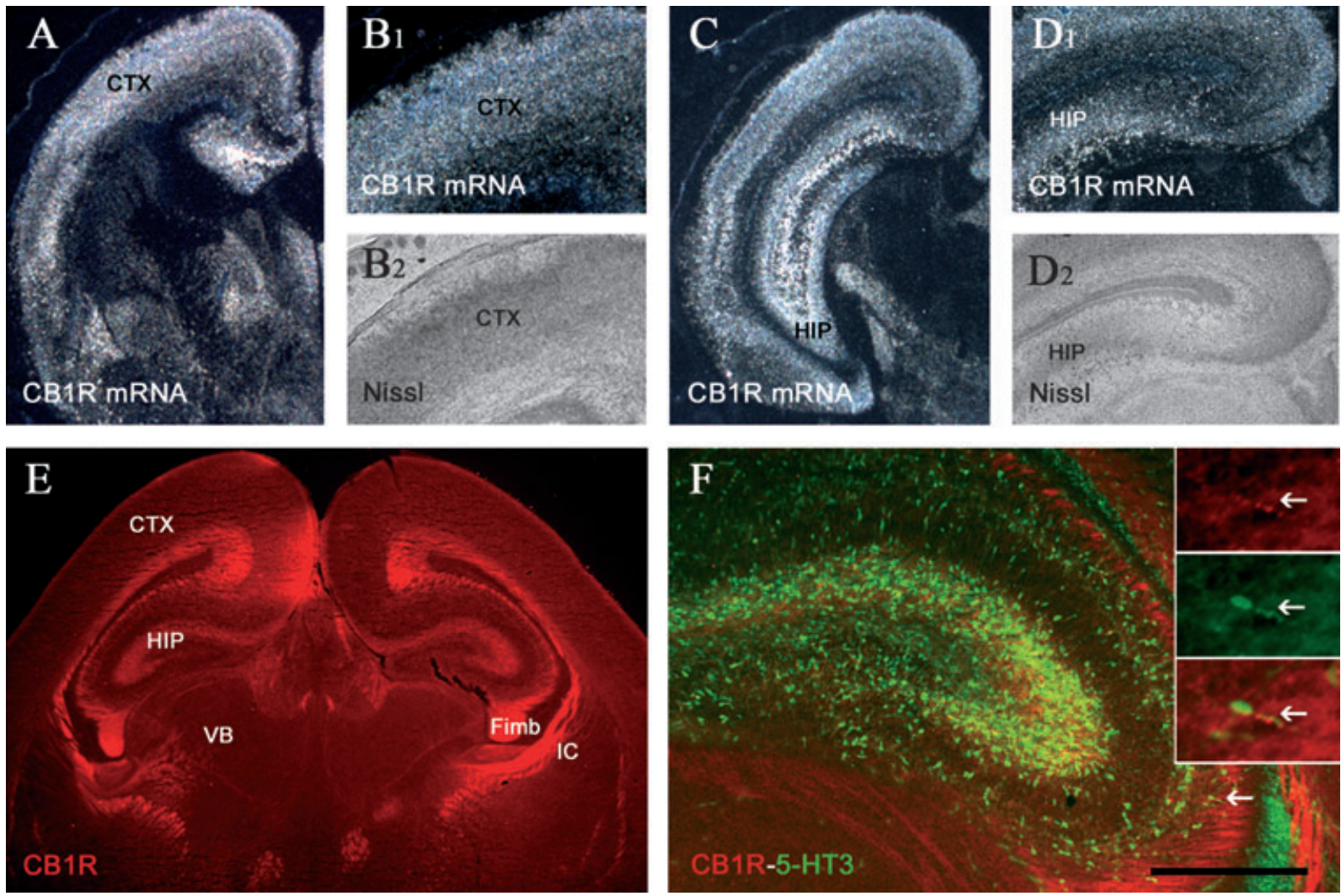

FIG. 4. Localization of $\mathrm{CB}_{1} \mathrm{R}$ at birth (P0). (A) In-situ hybridization showing a high level of $\mathrm{CB}_{1} \mathrm{R}$ expression in coronal sections of the rostral telencephalon. (B1 and B2) High-resolution images of the somatosensory cortex (CTX) shown in A. (B1) Expression of the $\mathrm{CB}_{1} \mathrm{R}$ mRNA. (B2) Bright-field view of the same region. (C) $I n$-situ hybridization showing high level of $\mathrm{CB}_{1} \mathrm{R}$ expression in the caudal telencephalon. (D1 and D2) High resolution of the hippocampal formation shown in $\mathrm{C}$. (D1) Expression of the $\mathrm{CB}_{1} \mathrm{R}$ mRNA. (D2) Bright-field view of the same region. Note that in the hippocampal formation both diffuse and spotty cellular expression could be observed (D1). (E and F) $\mathrm{CB}_{1} \mathrm{R}$ immunolabeling of an intermediate coronal section. Note that $\mathrm{CB}_{1} \mathrm{R}$ is strongly expressed in the hippocampus (HIP) and in numerous axonal tracts, such as the fimbria (Fimb) and cortical axons passing through the internal capsule (IC). (F) Coronal section of the hippocampus of a mouse expressing green fluorescent protein (GFP) under the control of the $5-\mathrm{HT}_{3 \mathrm{~A}}$ promoter stained for $\mathrm{CB}_{1} \mathrm{R}$ (red). Boxes show neurons expressing both $\mathrm{GFP}_{\mathrm{B}}$ and $\mathrm{CB}_{1} \mathrm{R}$ located in the $\mathrm{CA} 3$ region $(\mathrm{F}$, arrow). Bar: $\mathrm{A}-\mathrm{C}, 3 \mathrm{~mm}$; B1, B2, D1 and D2, $1.5 \mathrm{~mm}$;, $1.8 \mathrm{~mm} ; \mathrm{F}, 450 \mu \mathrm{m}$; insets in F, $70 \mu \mathrm{m}$. VB; ventrobasal thalamic nucleus.

partial redistribution of the receptor (data not shown). At the electron microscopic level the distribution of $\mathrm{CB}_{1} \mathrm{R}$ was also strikingly different in CP-55940-treated and control (vehicle-injected) embryos. In contrast to control animals (Fig. 3E and H), CP-55940-treated embryos showed a lack of $\mathrm{CB}_{1} \mathrm{R}$ immunolabeling on the axonal surface and a remarkable increase in the number of $\mathrm{CB}_{1} \mathrm{R}$-positive multivesicular bodies in the axonal tracts that occupied the full diameter of the relatively large axons (Fig. 3I and $\mathrm{K}-\mathrm{M}$ ). In addition, numerous large $\mathrm{CB}_{1} \mathrm{R}$-positive endosomes with a polycyclic profile were seen in the somato-dendritic compartments, suggesting frequent fusion events between these labeled organelles (Fig. 3J).

At birth (P0), both glutamatergic and GABAergic cell populations expressed $\mathrm{CB}_{1} \mathrm{R}$ (Fig. 4), as shown by using a bacterial artificial chromosome mouse line in which the GFP is expressed under the control of the $5-\mathrm{HT}_{3 \mathrm{~A}}$ promoter (Fig. $4 \mathrm{~F}$ ). In these mice, a large proportion of GFP-positive interneurons expressed $\mathrm{CB}_{1} \mathrm{R}$. This cell population corresponds to young GABAergic neurons that will later express cholecystokinin and vasoactive intestinal peptide (Vucurovic and Vitalis, unpublished results). In adult rat neocortex and hippocampus, $\mathrm{CB}_{1} \mathrm{R}$ is preferentially expressed in this cell population (Katona et al., 1999, 2000; Morales et al., 2004; Bodor et al., 2005; Hill et al., 2007). In addition, similarly to what was observed at E16.5, $\mathrm{CB}_{1} \mathrm{R}$ immunolabeling was also observed in numerous axonal tracts at $\mathrm{P} 0$. The mature location of $\mathrm{CB}_{1} \mathrm{R}$ became predominant around $\mathrm{P} 5$ as previously reported in the rat (in supporting Fig. S1) (Morozov \& Freund, 2003). From this stage, strong $\mathrm{CB}_{1} \mathrm{R}$ mRNA expression was mostly restricted to interneurons located in superficial and deep neocortical layers and in the hippocampus (in supporting Fig. S1), with $\mathrm{CB}_{1} \mathrm{R}$ immunolabeling localized to a dense local axonal network but no $\mathrm{CB}_{1} \mathrm{R}$ immunolabeling detected in axonal tracts.

In conclusion, $\mathrm{CB}_{1} \mathrm{Rs}$ are expressed very early by the majority of postmitotic projection neurons in the hippocampus and cerebral cortex. $\mathrm{CB}_{1}$ Rs are gradually translocated in the growing axons of these projection neurons. In these axons, $\mathrm{CB}_{1}$ Rs are localized on the axonal plasma membrane but an important proportion of $\mathrm{CB}_{1} \mathrm{Rs}$ is localized in endosomal structures. Axonal $\mathrm{CB}_{1} \mathrm{Rs}$ in the embryonic brain display an adequate physiological response to agonist stimulation (internalization followed by somato-dendritic translocation, as previously reported for $\mathrm{CB}_{1} \mathrm{R}$ in cultured hippocampal neurons by Leterrier et al., 2006), suggesting that embryonic $\mathrm{CB}_{1} \mathrm{Rs}$ are functionally competent. Importantly, these results also show that maternal cannabis consumption may lead to pharmacological activation of $\mathrm{CB}_{1} \mathrm{Rs}$ in the embryonic brain.

\section{Pharmacological or mutational activation or blockade of $C B_{1} R$ activity exerts opposite effects on the morphology of cultured hippocampal neurons}

Cerebral $\mathrm{CB}_{1} \mathrm{R}$ function has been mostly interpreted in the context of the regulation of synaptic transmission (Freund et al., 2003). However, the presence of functionally competent $\mathrm{CB}_{1}$ Rs on newly differentiated 
neurons and in growing axons indicates that $\mathrm{CB}_{1}$ Rs may participate in the regulation of neuronal development, as was also suggested by recent reports (Harkany et al., 2007, 2008; Watson et al., 2008). In order to precisely quantify the effects of $\mathrm{CB}_{1} \mathrm{R}$ activation, we first used low-density cultures of neurons isolated from the embryonic hippocampus, a brain structure expressing high levels of $\mathrm{CB}_{1} \mathrm{Rs}$. Rat hippocampal cultures represent a well-characterized model system that was successfully used in numerous studies to investigate neuronal development (Dotti et al., 1988; Bradke \& Dotti, 2000). In this system, at DIV4, neurites are already differentiated into axons and dendrites, which have acquired their morphological and structural features (Stage 3; Craig \& Banker, 1994).

In order to prepare primary neuronal cultures with a relatively high proportion of glutamatergic neurons, we isolated neurons from the hippocampus of rats at E17 (Carnegie stage 22, corresponding to E15.5 in mice). At this age, tangentially migrating GABAergic interneurons have not yet reached the primordium of hippocampus in high numbers (Jimenez et al., 2002). After 4 days in culture (DIV4), simultaneous immunodetection of $\mathrm{CB}_{1} \mathrm{R}$ and the $67 \mathrm{kDa}$ isoform of glutamic acid decarboxylase, a marker of GABAergic interneurons, was performed to investigate the expression of endogenous $\mathrm{CB}_{1} \mathrm{Rs}$. We found that the majority $(74.4 \pm 0.3 \%)$ of the neurons expressed $\mathrm{CB}_{1} \mathrm{R}$ and, among this population, only a minority $(4.6 \pm 0.7 \%)$ were GABAergic, showing that $\mathrm{CB}_{1}$ Rs are mostly expressed by glutamatergic neurons at this early stage (Fig. 5). Endogenous $\mathrm{CB}_{1} \mathrm{Rs}$ were located in vesicles in the somato-dendritic compartment as well as in axons and in axonal growth cones. This subcellular distribution was strongly reminiscent of the distribution previously shown in older neuronal cultures, where $\mathrm{CB}_{1}$ Rs are mostly expressed by GABAergic neurons (Irving et al., 2000; Coutts et al., 2001; Leterrier et al., 2004, 2006; McDonald et al., 2007).

Next, cultured hippocampal neurons were transfected with $\mathrm{CB}_{1} \mathrm{R}$ EGFP. Subneuronal localization of the transfected $\mathrm{CB}_{1} \mathrm{R}$ mirrored that of the native $C_{1} R$ and the transfected neurons were also predominantly of the glutamatergic phenotype (Benson et al., 1994) (data not shown). We then analysed the modifications of the axonal and dendritic morphology of individual neurons co-transfected with the structural marker DsRed2 and with $\mathrm{CB}_{1} \mathrm{R}$-EGFP. Neuronal $\mathrm{CB}_{1} \mathrm{Rs}$ have been shown to display significant spontaneous activation, which is partly mediated by endocannabinoids synthesized in the same neuron (Turu et al., 2007). This offers the opportunity to both enhance and inhibit steady-state $\mathrm{CB}_{1} \mathrm{R}$ activation. Neurons were treated with the vehicle, the agonist WIN (200 nM) or the antagonist/inverse agonist AM281 (200 nM) for $24 \mathrm{~h}$. We found that treatment with AM281 $(200 \mathrm{nM})$ dramatically increased the total number of primary dendrites (to $160.8 \pm 10.5 \%$ ) and the total dendritic length (to $205.3 \pm 23 \%$; Fig. $6 \mathrm{~A}$ and B). These effects were concentration-dependent with half-maximal effective concentration $\left(\mathrm{EC}_{50}\right)$ at $0.8 \pm 0.3 \mathrm{nM}$ of AM281 (Fig. 6C). Applications of WIN induced the opposite effect, without reaching significance threshold (Fig. 6B). Co-application of WIN abolished AM281 effects, indicating that the effects of AM281 were mediated by $\mathrm{CB}_{1}$ Rs (Fig. 6B). The axonal compartment did not show significant modification upon overnight pharmacological treatments. Interestingly, however, when WIN treatment (200 nM) was maintained between DIV3 and DIV10, the total arbor length of the axons was greatly decreased (to $55.4+5.0 \%$ ) (Fig. 6D). At this time point, AM281-treated neurons still showed a significantly larger number of dendrites (Fig. 6E). We obtained similar effects when the overnight incubations were realized using incubation media that had not been conditioned with glial cells, showing that endocannabinoids potentially present in the conditioned medium have no significant effect on neuronal development (data not shown). Finally, neurons transfected only with the structural marker DsRed2 only responded slightly to pharmacological treatments, demonstrating not only that the morphological effects were specifically mediated by the transfected $\mathrm{CB}_{1}$ Rs but also that endogenous $\mathrm{CB}_{1} \mathrm{Rs}$, present in the majority (75\%) of the neurons, had a limited influence on neuronal morphology in our experimental conditions (Fig. 6B).

The above results indicate that pharmacological activation and inhibition of transfected $\mathrm{CB}_{1}$ Rs significantly modify neuronal structure. However, pharmacological treatments act indiscriminately on every cell in the culture and thus the measured alterations may result from an indirect effect, mediated for example by non-neuronal cells, such as astrocytes, which are present in the culture in low numbers. Thus, we have confirmed the above results by co-transfecting sister cultures of DIV3 hippocampal neurons with DsRed2 and either $\mathrm{CB}_{1} \mathrm{R}$ EGFP or one of the two point mutants of $\mathrm{CB}_{1} \mathrm{R}$ that were recently reported by the group of D. Kendall to display either enhanced (T210I) or reduced (T210A) constitutive activity (D'Antona et al., 2006) as compared with non-mutated or wild-type $\mathrm{CB}_{1} \mathrm{Rs}$. We found that expression of T210I for $24 \mathrm{~h}$ (Fig. 7B) significantly reduced the number and length of primary and secondary dendrites (down to $67.8 \pm 8.8 \%$ and $67.0 \pm 10.0 \%$, respectively, Fig. 7D), as compared
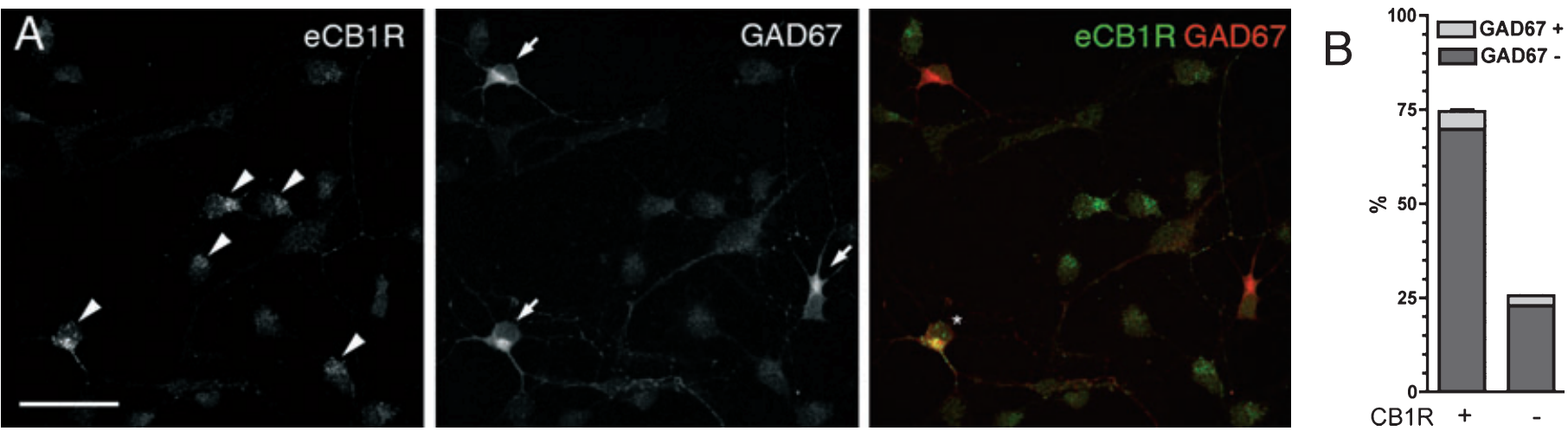

FIG. 5. Endogenous $\mathrm{CB}_{1}$ Rs are highly expressed in cultured glutamatergic hippocampal neurons at DIV4. (A) Immunohistochemical detection shows that at DIV4 the majority of cultured hippocampal neurons express endogenous $\mathrm{CB}_{1}$ receptors $\left(\mathrm{e} \mathrm{CB}_{1} \mathrm{Rs}\right.$ ) (arrowheads). Simultaneous detection of the $67 \mathrm{kDa}$ isoform of glutamic acid decarboxylase (GAD67) shows that only about $4-5 \%$ of the neurons are GABAergic (arrows) and that around half of these neurons express eCB $\mathrm{R}_{1}$ (asterisk). Bar $50 \mu \mathrm{m}$. (B) Quantification shows that around $75 \%$ of cultured hippocampal neurons are glutamatergic and express endogenous $\mathrm{CB}_{1} \mathrm{R}$ at $\mathrm{DIV} 4$. Results are mean \pm SEM. 

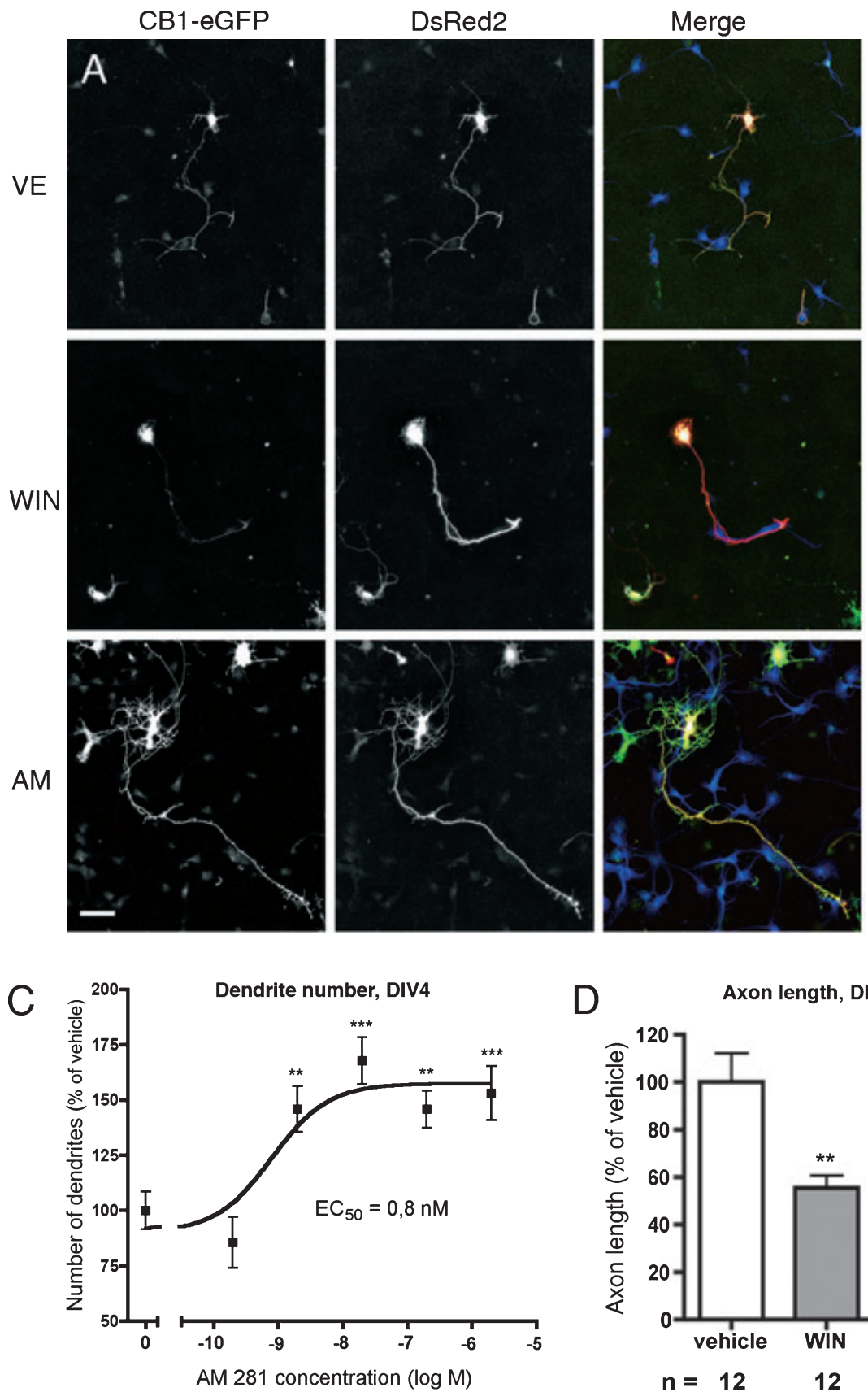

AM 281 concentration ( $\log M)$

D

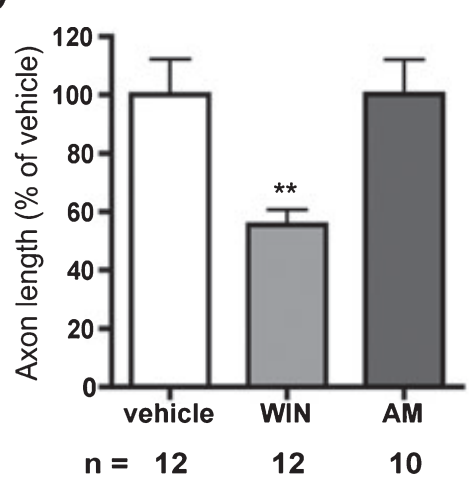

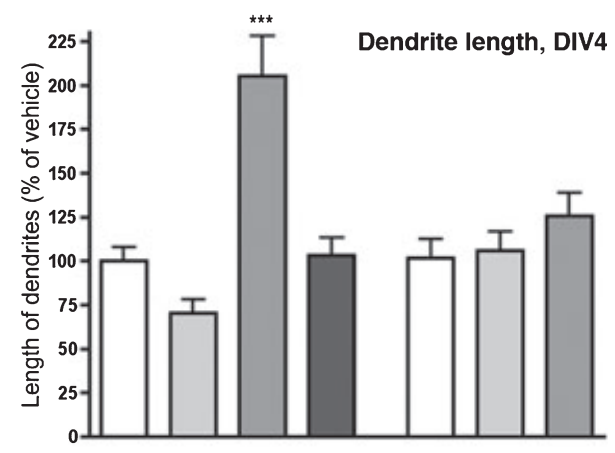
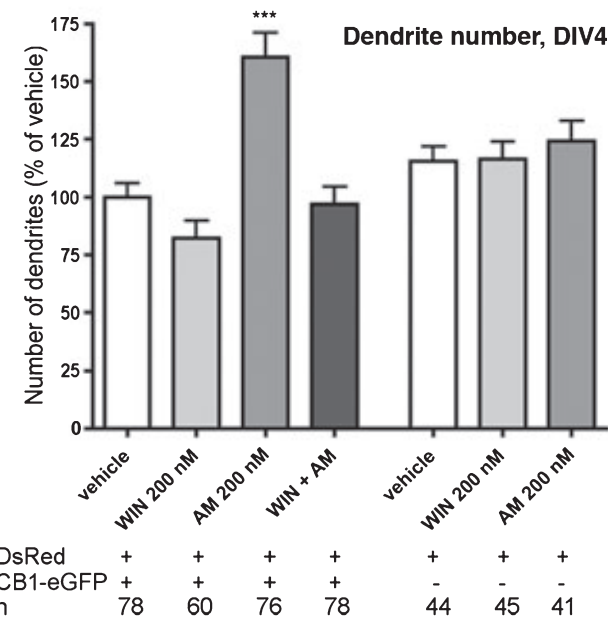

$E$

Dendrite number, DIV10

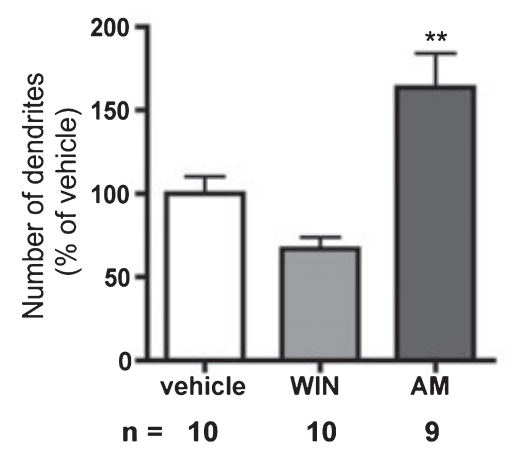

FIG. 6. Pharmacological activation or blockade of transfected $\mathrm{CB}_{1}$ Rs inversely modifies neuronal structure. Cultured hippocampal neurons were transfected with $\mathrm{CB}_{1} \mathrm{R}$-EGFP and the structural marker DsRed2 at DIV3. After treatment with $200 \mathrm{nM}$ of the $\mathrm{CB}_{1} \mathrm{R}$ agonist WIN or $200 \mathrm{nM}$ of the inverse agonist $\mathrm{AM} 281$ (AM), the neurite structure of $\mathrm{CB}_{1} \mathrm{R}$-EGFP-expressing cultured hippocampal neurons is profoundly modified in opposite directions. (A and $\mathrm{B}$ ) Overnight agonist treatment (WIN) reduces both the length and number of primary dendrites, whereas inverse agonist (AM) treatment results in a highly significant augmentation of these parameters as compared with vehicle (VE). Simultaneous application of WIN counteracts AM effects. In control neurons transfected only with the structural marker DsRed2, there is no significant morphological change with this treatment protocol. On the merged image, $\mathrm{CB}_{1} \mathrm{R}$ is labeled in green, DsRed in red and the neuronal marker microtubule-associated protein 2 in blue. Results are pooled from four independent experiments and are expressed as mean \pm SEM. (C) The effect of overnight AM281 treatment is dose-dependent with an $\mathrm{EC}_{50}$ of $0.8 \mathrm{nM}$. (D and E) Prolonged (7 days) treatment with $200 \mathrm{nM}$ WIN resulted in shorter axons and reduced dendrite number, whereas treatment with $200 \mathrm{nM}$ AM281 had opposite effects on the number of dendrites. Results are representative of at least two independent experiments and are expressed as mean \pm SEM. $* * P<0.01$ and $* * * P<0.001$ vs. vehicle.

with the expression of wild-type $\mathrm{CB}_{1} \mathrm{R}$ (Fig. 7A). On the contrary, expression of the hypoactive T210A mutant of $\mathrm{CB}_{1} \mathrm{R}$ (Fig. 7C) significantly increased the length of axons (up to $160.1 \pm 13.2 \%$ ) and also slightly increased the number and length of primary dendrites (to $110.9 \pm 6.3$ and $116.4 \pm 9.3 \%$, respectively, Fig. 7D).
In conclusion, we have shown that pharmacological or mutational manipulation of $\mathrm{CB}_{1} \mathrm{R}$ activity significantly modifies neuronal morphology of cultured hippocampal neurons. $\mathrm{CB}_{1} \mathrm{R}$ activation exerts an overall negative effect on the development of both axons and dendrites. Finally, the spontaneous activation of transfected wild-type 

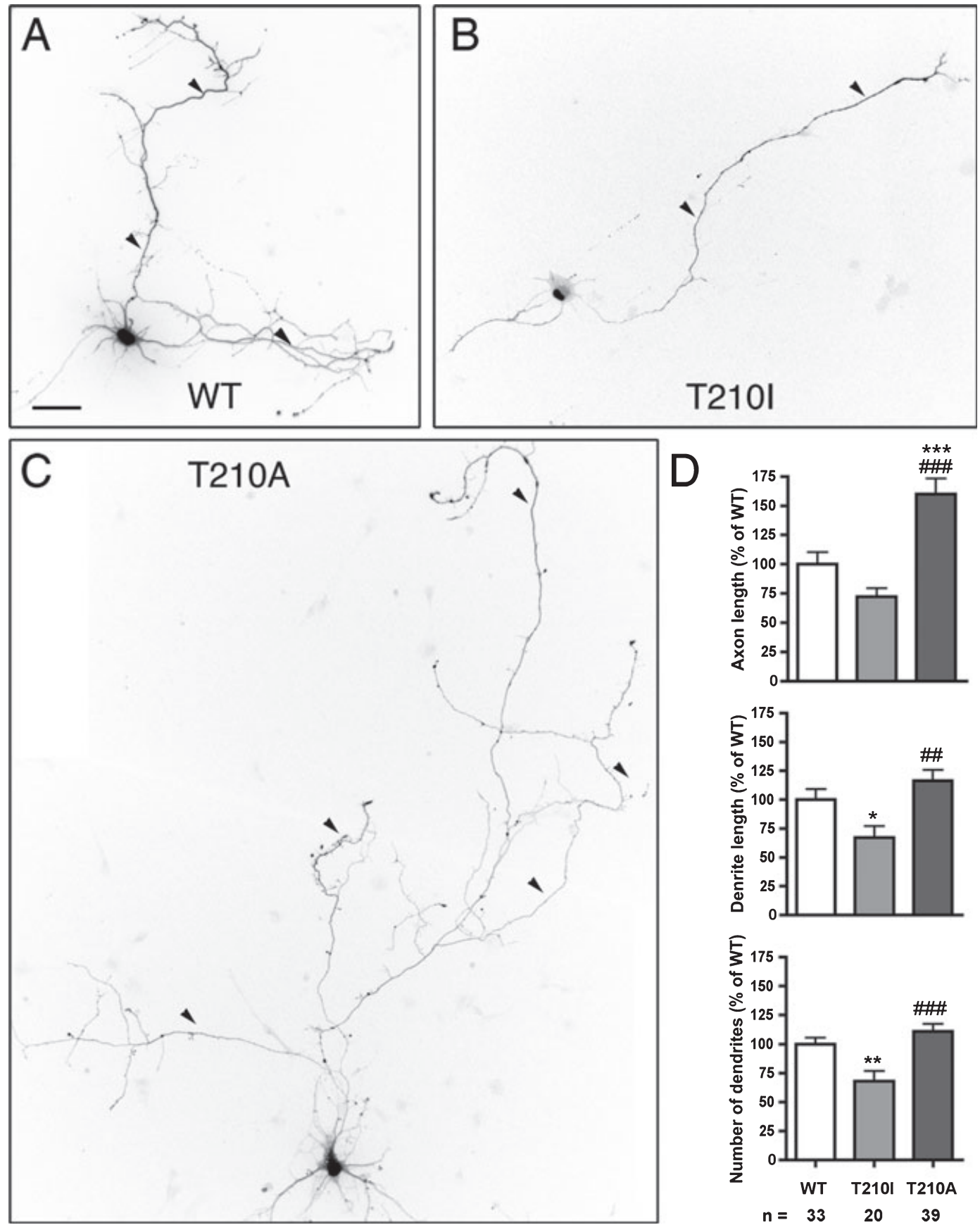

FIG. 7. Transfection of point mutants of $\mathrm{CB}_{1}$ Rs that display different levels of constitutive activity results in modified dendritic arborization and axon outgrowth. (A-C) Cultured hippocampal neurons were co-transfected at DIV3 with the structural marker DsRed2 and either wild-type CB $\mathrm{R}_{1} \mathrm{R}-\mathrm{EGFP}$ (wild-type) or the T210IEGFP over-active point mutant or the T210A-EGFP low-activity mutant. At DIV4, neurons were fixed and neuron morphology was quantified by NeuronJ. Bar $50 \mu \mathrm{m}$. (D) Mutational activation or inactivation exerts significant opposite effects on dendritic and axonal outgrowth. Axons are indicated by arrowheads. Results are pooled from two independent experiments and are expressed as mean \pm SEM. ${ }^{*} P<0.05,{ }^{*} P<0.01$ and ${ }^{*} * * P<0.001$ vs. vehicle. ${ }^{\#} P<0.01$ and $\#$ \# $P<0.001$ vs. T210I-CB 1 R.

$\mathrm{CB}_{1} \mathrm{Rs}$ has a significant negative effect on the neuritic development of isolated hippocampal neurons, as demonstrated by the effect of AM281 treatment or the morphological difference between neurons transfected with wild-type $\mathrm{CB}_{1} \mathrm{R}$ vs. T210I-CB $\mathrm{CB}_{1}$.

\section{Discussion}

We report that, starting from E12.5, $\mathrm{CB}_{1} \mathrm{Rs}$ are strongly expressed in both reelin-expressing Cajal-Retzius cells and newly differentiated postmitotic glutamatergic neurons of the mouse telencephalon. $\mathrm{CB}_{1} \mathrm{R}$ protein is localized first to somato-dendritic endosomes and at later developmental stages it localizes mostly to developing axons (see supporting Fig. S2). In young axons, $\mathrm{CB}_{1}$ Rs localize to both the axolemma and large, often multivesicular endosomes. We also show that maternal treatment with cannabinoid agonist results in internalization of embryonic $\mathrm{CB}_{1} \mathrm{Rs}$, suggesting functional competence. Finally, by using in-vitro assays we demonstrate that activation of $\mathrm{CB}_{1} \mathrm{R}$ signaling acts as a negative regulatory signal for dendritic and axonal outgrowth. 


\section{$C B_{1} R$ expression in the developing telencephalon}

Strong and transient $\mathrm{CB}_{1} \mathrm{R}$ binding and mRNA expression were described in the rodent cerebral cortex at early developmental stages (reviewed in Fernandez-Ruiz et al., 1999). Later at E14-P4, during the period of intense axonal and dendritic outgrowth (Lopez-Bendito et al., 2003), $\mathrm{CB}_{1} \mathrm{R}$ mRNA is still highly expressed by cortical and hippocampal areas, and, importantly, white matter areas containing the developing axons of these neurons also show transiently strong expression of functional $\mathrm{CB}_{1}$ Rs (Fernandez-Ruiz et al., 1999). This transiently strong expression in telencephalic glutamatergic neurons was also suggested by studies in human fetuses showing $\mathrm{CB}_{1} \mathrm{R}$ binding in axon-rich regions such as the capsula interna and pyramidal tracts (Mato et al., 2003; Fride, 2004). Axonal expression was recently confirmed by immunohistochemistry (Berghuis et al., 2007) and in the present study we provide the first comprehensive high-resolution description of $\mathrm{CB}_{1} \mathrm{R}$ localization during the early stages of cortical and hippocampal development. Thus, we show that $\mathrm{CB}_{1} \mathrm{Rs}$ are highly expressed from the earliest stages of neuronal differentiation by postmitotic preplate neurons at E12.5. Indeed, starting from the earliest stage investigated, $\mathrm{CB}_{1} \mathrm{R}$ mRNA and protein expression was restricted to Tuj-1-immunopositive committed neurons and was never observed in the ventricular zone, indicating that, in contrast to adult progenitor cells (Jin et al., 2004; Aguado et al., 2005, 2006; Jiang et al., 2005), in the rodent embryonic forebrain $\mathrm{CB}_{1} \mathrm{R}$ expression is restricted to postmitotic neurons. This is in line with data reported in the chick and zebrafish embryonic brainstem and spinal cord (Watson et al., 2008) during the preparation of the present article. We also identify $\mathrm{CB}_{1} \mathrm{R}$ expression in a subpopulation of reelin-secreting CajalRetzius cells. Cajal-Retzius cells participate in the regulation of the phenotype of radial glial cells and the inside-out formation of the cortical plate (reviewed by Super et al., 1998), as well as in the development of cortical dendrites (MacLaurin et al., 2007). These results suggest that $C_{1} R$ signaling could participate in the initial steps of cortical plate and hippocampal formation and in the development of the glutamatergic projections. We also show that, at later developmental stages, $\mathrm{CB}_{1} \mathrm{Rs}$ are gradually translocated to axon tracts composed of fascicles of corticofugal axons. In contrast with the work of the group of Harkany (Berghuis et al., 2007), reporting functional significance of $\mathrm{CB}_{1} \mathrm{R}$ expression in migrating GABAergic neurons before birth and $\mathrm{CB}_{1} \mathrm{R}$ expression in 'GABAergic interneurons during late gestation as they were undergoing intracortical tangential or radial migration', we did not found notable expression of $\mathrm{CB}_{1} \mathrm{R}$ mRNA or $\mathrm{CB}_{1} \mathrm{R}$ protein in the ganglionic eminences or in tangentially migrating interneurons in the subventricular zones. Finally, our data indicate that, at birth, $\mathrm{CB}_{1} \mathrm{R}$ shows an expression pattern intermediate between embryonic and adult phenotype, the latter being firmly acquired only after P5.

\section{Embryonic $C B_{1} R$ s are localized to endosomes before acquiring functional expression on the axolemma}

At the ultrastructural level $\mathrm{CB}_{1} \mathrm{R}$ was almost exclusively associated with the outer membrane of large and complex endosomes in preplate neurons. At later stages, $\mathrm{CB}_{1} \mathrm{Rs}$ were still localized to complex endosomes in the somato-dendritic region of cortical plate neurons but in developing axonal tracts a significant number of $\mathrm{CB}_{1} \mathrm{Rs}$ were localized to round and multivesicular endosomes, accompanied by expression on the axonal plasma membrane. Endosomal staining was associated with the cytoplasmic side of the organelles in accordance with the fact that the anti-CB $\mathrm{CB}_{1} \mathrm{R}$ antibody used was raised against the C-terminus of the receptor. Notably, a similar, mostly endosomal localization was also reported in the somato-dendritic region of adult cortical and hippocampal neurons (Katona et al., 2000; Bodor et al., 2005), as well as in the somato-dendritic region of mature cultured hippocampal neurons (Leterrier et al., 2006; McDonald et al., 2007) and in cell lines (Leterrier et al., 2004; D'Antona et al., 2006; Ellis et al., 2006; Wu et al., 2008), where this endosomal localization of $\mathrm{CB}_{1} \mathrm{Rs}$ is the result of intense constitutive endocytosis. This cycling is tightly associated with basal receptor activation, partly resulting from autocrine activation by endogenous 2-arachidonoylglycerol (2-AG) produced by diacylglycerol lipases (Turu et al., 2007). Thus, the finding that $\mathrm{CB}_{1} \mathrm{Rs}$ are mostly endosomal in the embryonic brain raises the possibility that these receptors are significantly activated in the embryonic brain. Interestingly, in embryonic axons, where $\mathrm{CB}_{1} \mathrm{Rs}$ are strongly internalized, both diacylglycerol lipases $\alpha$ and $\beta$ are highly expressed (Bisogno et al., 2003; Watson et al., 2008), suggesting that $\mathrm{CB}_{1}$ Rs may be significantly activated by a putative autocrine or paracrine production of 2-AG, leading to permanent activation and internalization of $\mathrm{CB}_{1} \mathrm{Rs}$ in both the somato-dendritic region and axons. This endocytic stimulation is not maximal, as shown by the effect of acute agonist treatment, which leads to a more enhanced endosomal phenotype, characterized by complete depletion of $\mathrm{CB}_{1} \mathrm{R}$ from the axonal surface and enhanced formation of multivesicular endosomes, ultimately leading to significant translocation from axons to the somato-dendritic compartment of glutamatergic neurons. Interestingly, in mature neurons $\mathrm{CB}_{1} \mathrm{Rs}$ appear to be efficiently recycled after moderate activation but more sustained activation directs $\mathrm{CB}_{1} \mathrm{Rs}$ to the lysosomal degradation pathway through interaction with G-protein-coupled receptor-associated sorting protein (GASP-1) protein (Martini et al., 2007; Tappe-Theodor et al., 2007). Thus, extrapolation of these results to our data would suggest that $\mathrm{CB}_{1} \mathrm{Rs}$, moderately activated by autocrine 2-AG in embryonic axons, are possibly efficiently recycled locally, whereas more pronounced activation by exogenous cannabinoid ligands possibly leads to somato-dendritic translocation followed by lysosomal degradation.

It should also be noted that considering axonal multivesicular endosomes solely as predegradative and degradative compartments is probably an oversimplification, as we have often found $\mathrm{CB}_{1} \mathrm{Rs}$ localized to multivesicular endosomes in untreated animals in the embryonic brain (present study) as well as in untreated DIV9 cultured hippocampal neurons (Leterrier et al., 2006). Interestingly, recent data suggest that these endosomes may be specialized intermediates characteristic to the somatodendro-axonal transcytotic pathway, which is responsible for the correct axonal targeting of axolemmal proteins such as $\mathrm{NgCam}$ (Yap et al., 2008) or $\mathrm{CB}_{1} \mathrm{R}$ (Leterrier et al., 2006). The definition of the exact role of these organelles clearly necessitates further investigation.

In conclusion, our results indicate that: (i) $\mathrm{CB}_{1} \mathrm{Rs}$ in the embryonic brain are functional, as was also previously indicated by efficient GTP $\gamma \mathrm{S}$ binding in the rat (Berrendero et al., 1998) and human brain (Mato et al., 2003); (ii) $\mathrm{CB}_{1} \mathrm{Rs}$ are moderately but significantly activated by endocannabinoids, presumably through autocrine production of 2-AG; and (iii) maternal cannabinoid consumption may lead to over-activation and subneuronal translocation of embryonic $\mathrm{CB}_{1}$ Rs.

\section{Pharmacological activation or blockade of $\mathrm{CB}_{1} R$ s inversely modifies the morphology of pyramidal neurons}

What is the physiological role of activated $\mathrm{CB}_{1} \mathrm{Rs}$ in developing projection axons, well before the establishment of synaptic functions? 
Our results show that stimulation or inhibition of the $\mathrm{CB}_{1} \mathrm{R}$ activation state by pharmacological ligands or point mutation of T210 inversely regulates neuron morphology. Interestingly, the significant effect of antagonist/inverse agonist treatment as well as the difference between wild-type and $\mathrm{T} 210 \mathrm{~A}-\mathrm{CB}_{1} \mathrm{R}$ indicate that transfected wild-type $\mathrm{CB}_{1} \mathrm{Rs}$ are sufficiently activated to exert a notable inhibiting effect, without addition of an exogenous agonist. Because the effects were identical in neurons incubated with glia-conditioned or with fresh unconditioned medium, the source of this basal activation is probably either the constitutive activity of $\mathrm{CB}_{1} \mathrm{Rs}$, the cell autonomous autocrine production of 2-AG (Turu et al., 2007) or a combination of both. The dominant effect of $\mathrm{CB}_{1} \mathrm{R}$ activation in young DIV3 neurons is the inhibition of dendritogenesis, dendritic outgrowth and, to a lesser extent, axonal outgrowth, the latter effect being more pronounced at later developmental stages. Previously, $\mathrm{CB}_{1}$ Rs were shown in vitro both to positively regulate fibroblast growth factor (FGF)-stimulated axonal growth of cerebellar neurons (Williams et al., 2003) and negatively regulate neurite development of GABAergic neurons (Berghuis et al., 2005). In addition, recent in-vivo data show that, in chick and zebrafish embryos, $\mathrm{CB}_{1} \mathrm{R}$ gene knockdown results in defective axonal growth and fasciculation (Watson et al., 2008). Finally, and rather at variance with our direct in-vitro data, in $\mathrm{CB}_{1} \mathrm{R}$ knockout mice the spine density and field area of basal dendrites of layer III pyramidal neurons are significantly reduced as compared with wild-type mice (Ballesteros-Yanez et al., 2007). Our results, obtained in isolated hippocampal neurons, suggest that the dominant cellautonomous effect of $\mathrm{CB}_{1} \mathrm{R}$ stimulation (pharmacological or mutational) is the inhibition of both axon and dendrite development. It should, however, be kept in mind that our results were obtained by using transfected neurons and that effects obtained by pharmacological manipulation of endogenous $\mathrm{CB}_{1} \mathrm{Rs}$, although pointing to the same direction, did not reach the significance threshold in our experimental system. Previously, the existence of powerful compensatory mechanisms and high functional plasticity were proposed to explain the lack of marked developmental central nervous system deficits in the available null mutant mice, deficient for different components of the endocannabinoid system (Harkany et al., 2008).

Taken together, the overall negative regulatory role in the neurite development of cortical projection neurons suggests that embryonic $\mathrm{CB}_{1} \mathrm{R}$ signaling is one of the numerous players that help the establishment of correct neuronal connectivity. Data reported in the present study point to an interesting putative mechanism to explore in order to better understand the development of reported glutamatergic dysfunction in offspring following maternal cannabis consumption.

\section{Note added in revision}

During the revision process of this manuscript, Mulder et al. (2008) have published a study that includes interesting data on $\mathrm{CB}_{1} \mathrm{R}$ expression and function in glutamatergic neurons of the embryonic rodent brain. The expression pattern of $\mathrm{CB}_{1} \mathrm{Rs}$ is well correlated with data reported in the present study, with the exception of the proliferative subventricular zone where, at variance with our data, they report significant levels of $\mathrm{CB}_{1} \mathrm{R}$ expression. In vitro, Mulder et al. (2008) find that endogenous $\mathrm{CB}_{1} \mathrm{Rs}$ inhibit dendritic development of cultured cortical neurons but, at variance with the present report where we used hippocampal neurons, they report a stimulating role for $\mathrm{CB}_{1} \mathrm{Rs}$ in axonal growth. Finally, Mulder et al. (2008) present qualitative data on the in-vivo significance of embryonic $\mathrm{CB}_{1} \mathrm{R}$ expression by showing that pharmacological or genetic ablation of $\mathrm{CB}_{1}$ Rs results in deficits of neuronal progenitor proliferation and axon fasciculation.

\section{Supporting information}

Additional supporting information may be found in the online version of this article:

Fig. S1. Location of $\mathrm{CB}_{1} \mathrm{R}$ on cortical neurons at $\mathrm{P} 5$ and in adult mice. Fig. S2. Summary of $\mathrm{CB}_{1} \mathrm{R}$ expression profile during early cortical development in mice.

Video S1. Three D reconstruction of a confocal stack from the cortical preplate of an E12.5 embryo.

Please note: Wiley-Blackwell are not responsible for the content or functionality of any supporting materials supplied by the authors. Any queries (other than missing material) should be directed to the corresponding author for the article.

\section{Acknowledgements}

This work was funded by the INSERM and CNRS. We thank Patricia Gaspar and Olivier Cases for helpful discussions, Fabien Pasteau for precious technical help, Ksenija Vucurovic, a student of the 'Ecole de l'INSERM', and the graduate students Caroline Heymann, Astrid Walrant, Inès Khalfallah, Vincent Marzloff and Emilie Warrick who participated in this project.

\section{Abbreviations}

2-AG, 2-arachidonoylglycerol; $\mathrm{CB}_{1} \mathrm{R}$, type 1 cannabinoid receptor; DAPI, 4'6diamidino-2-phenylindole $2 \mathrm{HCl}$; DIV, days in vitro; DPBS, Dulbecco's phosphate-buffered saline; E, embryonic day; EGFP, enhanced green fluorescent protein; GFP, green fluorescent protein; P, postnatal day; Tuj-1, neuronspecific beta III tubulin; WIN, WIN55,212-2.

\section{References}

Aguado, T., Monory, K., Palazuelos, J., Stella, N., Cravatt, B., Lutz, B., Marsicano, G., Kokaia, Z., Guzman, M. \& Galve-Roperh, I. (2005) The endocannabinoid system drives neural progenitor proliferation. FASEB J., 19, 1704-1706.

Aguado, T., Palazuelos, J., Monory, K., Stella, N., Cravatt, B., Lutz, B., Marsicano, G., Kokaia, Z., Guzman, M. \& Galve-Roperh, I. (2006) The endocannabinoid system promotes astroglial differentiation by acting on neural progenitor cells. J. Neurosci., 26, 1551-1561.

Antonelli, T., Tanganelli, S., Tomasini, M.C., Finetti, S., Trabace, L., Steardo, L., Sabino, V., Carratu, M.R., Cuomo, V. \& Ferraro, L. (2004) Long-term effects on cortical glutamate release induced by prenatal exposure to the cannabinoid receptor agonist (R)-(+)-[2,3-dihydro-5-methyl-3-(4-morpholinyl-methyl)pyrrolo[1,2,3-de]-1,4-benzoxazin-6-yl]-1-naphthalenylmethanone: an in vivo microdialysis study in the awake rat. Neuroscience, 124, $367-375$.

Antonelli, T., Tomasini, M.C., Tattoli, M., Cassano, T., Tanganelli, S., Finetti, S., Mazzoni, E., Trabace, L., Steardo, L., Cuomo, V. \& Ferraro, L. (2005) Prenatal exposure to the CB1 receptor agonist WIN 55,212-2 causes learning disruption associated with impaired cortical NMDA receptor function and emotional reactivity changes in rat offspring. Cereb. Cortex, 15, 2013-2020.

Ballesteros-Yanez, I., Valverde, O., Ledent, C., Maldonado, R. \& DeFelipe, J. (2007) Chronic cocaine treatment alters dendritic arborization in the adult motor cortex through a CB1 cannabinoid receptor-dependent mechanism. Neuroscience, 146, 1536-1545.

Barch, D.M. (2005) The cognitive neuroscience of schizophrenia. Annu. Rev. Clin. Psychol., 1, 321-353.

Benson, D.L., Watkins, F.H., Steward, O. \& Banker, G. (1994) Characterization of GABAergic neurons in hippocampal cell cultures. J. Neurocytol., 23, 279-295.

Berghuis, P., Dobszay, M.B., Wang, X., Spano, S., Ledda, F., Sousa, K.M., Schulte, G., Ernfors, P., Mackie, K., Paratcha, G., Hurd, Y.L. \& Harkany, T. (2005) Endocannabinoids regulate interneuron migration and morphogenesis by transactivating the TrkB receptor. Proc. Natl. Acad. Sci. U.S.A., 102, 19115-19120.

Berghuis, P., Rajnicek, A.M., Morozov, Y.M., Ross, R.A., Mulder, J., Urban, G.M., Monory, K., Marsicano, G., Matteoli, M., Canty, A., Irving, A.J., Katona, I., Yanagawa, Y., Rakic, P., Lutz, B., Mackie, K. \& Harkany, T. (2007) Hardwiring the brain: endocannabinoids shape neuronal connectivity. Science, 316, 1212-1216. 
Berrendero, F., Garcia-Gil, L., Hernandez, M.L., Romero, J., Cebeira, M., de Miguel, R., Ramos, J.A. \& Fernandez-Ruiz, J.J. (1998) Localization of mRNA expression and activation of signal transduction mechanisms for cannabinoid receptor in rat brain during fetal development. Development, $\mathbf{1 2 5}, 3179-3188$.

Bisogno, T., Howell, F., Williams, G., Minassi, A., Cascio, M.G., Ligresti, A., Matias, I., Schiano-Moriello, A., Paul, P., Williams, E.J., Gangadharan, U., Hobbs, C., Di Marzo, V. \& Doherty, P. (2003) Cloning of the first sn1-DAG lipases points to the spatial and temporal regulation of endocannabinoid signaling in the brain. J. Cell Biol., 163, 463-468.

Bodor, A.L., Katona, I., Nyiri, G., Mackie, K., Ledent, C., Hajos, N. \& Freund, T.F. (2005) Endocannabinoid signaling in rat somatosensory cortex: laminar differences and involvement of specific interneuron types. J. Neurosci., 25, 6845-6856.

Bonnin, A., de Miguel, R., Hernandez, M.L., Ramos, J.A. \& Fernandez-Ruiz, J.J. (1995) The prenatal exposure to delta 9-tetrahydrocannabinol affects the gene expression and the activity of tyrosine hydroxylase during early brain development. Life Sci., 56, 2177-2184.

Bonnin, A., de Miguel, R., Castro, J.G., Ramos, J.A. \& Fernandez-Ruiz, J.J. (1996) Effects of perinatal exposure to delta 9-tetrahydrocannabinol on the fetal and early postnatal development of tyrosine hydroxylase-containing neurons in rat brain. J. Mol. Neurosci., 7, 291-308.

Bradke, F. \& Dotti, C.G. (2000) Establishment of neuronal polarity: lessons from cultured hippocampal neurons. Curr. Opin. Neurobiol., 10, 574-581.

Castaldo, P., Magi, S., Gaetani, S., Cassano, T., Ferraro, L., Antonelli, T., Amoroso, S. \& Cuomo, V. (2007) Prenatal exposure to the cannabinoid receptor agonist WIN 55,212-2 increases glutamate uptake through overexpression of GLT1 and EAAC1 glutamate transporter subtypes in rat frontal cerebral cortex. Neuropharmacology, 53, 369-378

Coutts, A.A., Anavi-Goffer, S., Ross, R.A., MacEwan, D.J., Mackie, K., Pertwee, R.G. \& Irving, A.J. (2001) Agonist-induced internalization and trafficking of cannabinoid CB1 receptors in hippocampal neurons. J. Neurosci., 21, 2425-2433.

Craig, A.M. \& Banker, G. (1994) Neuronal polarity. Anпи. Rev. Neurosci., 17, 267-310.

D’Antona, A.M., Ahn, K.H. \& Kendall, D.A. (2006) Mutations of CB1 T210 produce active and inactive receptor forms: correlations with ligand affinity, receptor stability, and cellular localization. Biochemistry, 45, 5606-5617.

Del Río, J.A., Martínez, A., Auladell, C. \& Soriano, E. (2000) Developmental history of the subplate and developing white matter in the murine neocortex. Neuronal organization and relationship with the main afferent systems at embryonic and perinatal stages. Cereb. Cortex, 10, 784-801.

Dotti, C.G., Sullivan, C.A. \& Banker, G.A. (1988) The establishment of polarity by hippocampal neurons in culture. J. Neurosci., 8, 1454-1468.

Ebrahim, S.H. \& Gfroerer, J. (2003) Pregnancy-related substance use in the United States during 1996-1998. Obstet. Gynecol., 101, 374-379.

Ellis, J., Pediani, J.D., Canals, M., Milasta, S. \& Milligan, G. (2006) Orexin-1 receptor-cannabinoid $\mathrm{CB} 1$ receptor heterodimerization results in both liganddependent and -independent coordinated alterations of receptor localization and function. J. Biol. Chem., 281, 38812-38824.

Fernandez-Ruiz, J.J., Berrendero, F., Hernandez, M.L., Romero, J. \& Ramos, J.A. (1999) Role of endocannabinoids in brain development. Life Sci., 65, $725-736$

Fontaine, B. \& Changeux, J.P. (1989) Localization of nicotinic acetylcholine receptor alpha-subunit transcripts during myogenesis and motor endplate development in the chick. J. Cell Biol., 108, 1025-1037.

Freund, T.F., Katona, I. \& Piomelli, D. (2003) Role of endogenous cannabinoids in synaptic signaling. Physiol. Rev., 83, 1017-1066.

Fride, E. (2004) The endocannabinoid-CB(1) receptor system in pre- and postnatal life. Eur. J. Pharmacol., 500, 289-297.

Fried, P.A. \& Smith, A.M. (2001) A literature review of the consequences of prenatal marihuana exposure. An emerging theme of a deficiency in aspects of executive function. Neurotoxicol. Teratol., 23, 1-11.

Garcia-Gil, L., de Miguel, R., Romero, J., Perez, A., Ramos, J.A. \& FernandezRuiz, J.J. (1999) Perinatal delta9-tetrahydrocannabinol exposure augmented the magnitude of motor inhibition caused by GABA(B), but not GABA(A), receptor agonists in adult rats. Neurotoxicol. Teratol., 21, 277-283.

Goslin, K. \& Banker, G. (1989) Experimental observations on the development of polarity by hippocampal neurons in culture. J. Cell Biol., 108, 1507-1516.

Hanyaloglu, A.C. \& von Zastrow, M. (2008) Regulation of GPCRs by membrane trafficking and its potential implications. Annu. Rev. Pharmacol. Toxicol., 48, 537-568.

Harkany, T., Guzman, M., Galve-Roperh, I., Berghuis, P., Devi, L.A. \& Mackie, K. (2007) The emerging functions of endocannabinoid signaling during CNS development. Trends Pharmacol. Sci., 28, 83-92.
Harkany, T., Keimpema, E., Barabas, K. \& Mulder, J. (2008) Endocannabinoid functions controlling neuronal specification during brain development. Mol. Cell. Endocrinol., 286, S84-S90.

Hill, E.L., Gallopin, T., Ferezou, I., Cauli, B., Rossier, J., Schweitzer, P. \& Lambolez, B. (2007) Functional CB1 receptors are broadly expressed in neocortical GABAergic and glutamatergic neurons. J. Neurophysiol., 97, $2580-2589$.

Hutchings, D.E., Gamagaris, Z., Miller, N. \& Fico, T.A. (1989) The effects of prenatal exposure to delta-9-tetrahydrocannabinol on the rest-activity cycle of the preweanling rat. Neurotoxicol. Teratol., 11, 353-356.

Irving, A.J., Coutts, A.A., Harvey, J., Rae, M.G., Mackie, K., Bewick, G.S. \& Pertwee, R.G. (2000) Functional expression of cell surface cannabinoid $\mathrm{CB}(1)$ receptors on presynaptic inhibitory terminals in cultured rat hippocampal neurons. Neuroscience, 98, 253-262.

Jiang, W., Zhang, Y., Xiao, L., Van Cleemput, J., Ji, S.P., Bai, G. \& Zhang, X. (2005) Cannabinoids promote embryonic and adult hippocampus neurogenesis and produce anxiolytic- and antidepressant-like effects. J. Clin. Invest., 115, 3104-3116.

Jimenez, D., Lopez-Mascaraque, L.M., Valverde, F. \& De Carlos, J.A. (2002) Tangential migration in neocortical development. Dev. Biol., 244, 155-169.

Jin, K., Xie, L., Kim, S.H., Parmentier-Batteur, S., Sun, Y., Mao, X.O., Childs, J. \& Greenberg, D.A. (2004) Defective adult neurogenesis in CB1 cannabinoid receptor knockout mice. Mol. Pharmacol., 66, 204-208.

Jolimay, N., Franck, L., Langlois, X., Hamon, M. \& Darmon, M. (2000) Dominant role of the cytosolic C-terminal domain of the rat 5-HT1B receptor in axonal-apical targeting. J. Neurosci., 20, 9111-9118.

Katona, I., Sperlagh, B., Sik, A., Kafalvi, A., Vizi, E.S., Mackie, K. \& Freund, T.F. (1999) Presynaptically located CB1 cannabinoid receptors regulate GABA release from axon terminals of specific hippocampal interneurons. J. Neurosci., 19, 4544-4558.

Katona, I., Sperlagh, B., Magloczky, Z., Santha, E., Kofalvi, A., Czirjak, S., Mackie, K., Vizi, E.S. \& Freund, T.F. (2000) GABAergic interneurons are the targets of cannabinoid actions in the human hippocampus. Neuroscience, 100, 797-804

Katona, I., Urbán, G.M., Wallace, M., Ledent, C., Jung, K.M., Piomelli, D., Mackie, K. \& Freund, T.F. (2006) Molecular composition of the endocannabinoid system at glutamatergic synapses. J. Neurosci., 26, 5628-5637.

Kawamura, Y., Fukaya, M., Maejima, T., Yoshida, T., Miura, E., Watanabe, M., Ohno-Shosaku, T. \& Kano, M. (2006) The CB1 cannabinoid receptor is the major cannabinoid receptor at excitatory presynaptic sites in the hippocampus and cerebellum. J. Neurosci., 26, 2991-3001.

Leterrier, C., Bonnard, D., Carrel, D., Rossier, J. \& Lenkei, Z. (2004) Constitutive endocytic cycle of the CB1 cannabinoid receptor. J. Biol. Chem., 279, 36013-36021.

Leterrier, C., Laine, J., Darmon, M., Boudin, H., Rossier, J. \& Lenkei, Z. (2006) Constitutive activation drives compartment-selective endocytosis and axonal targeting of type 1 cannabinoid receptors. J. Neurosci., 26, 3141-3153.

Lopez-Bendito, G., Lujan, R., Shigemoto, R., Ganter, P., Paulsen, O. \& Molnar, Z. (2003) Blockade of GABA(B) receptors alters the tangential migration of cortical neurons. Cereb. Cortex, 13, 932-942.

MacLaurin, S.A., Krucker, T. \& Fish, K.N. (2007) Hippocampal dendritic arbor growth in vitro: regulation by Reelin-Disabled-1 signaling. Brain Res., 1172, $1-9$

Martini, L., Waldhoer, M., Pusch, M., Kharazia, V., Fong, J., Lee, J.H. Freissmuth, C. \& Whistler, J.L. (2007) Ligand-induced down-regulation of the cannabinoid 1 receptor is mediated by the G-protein-coupled receptorassociated sorting protein GASP1. FASEB J., 21, 802-811.

Mato, S., Del Olmo, E. \& Pazos, A. (2003) Ontogenetic development of cannabinoid receptor expression and signal transduction functionality in the human brain. Eur. J. Neurosci., 17, 1747-1754.

McDonald, N.A., Henstridge, C.M., Connolly, C.N. \& Irving, A.J. (2007) An essential role for constitutive endocytosis, but not activity, in the axonal targeting of the CB1 cannabinoid receptor. Mol. Pharmacol., 71, 976-984.

Meijering, E., Jacob, M., Sarria, J.C., Steiner, P., Hirling, H. \& Unser, M. (2004) Design and validation of a tool for neurite tracing and analysis in fluorescence microscopy images. Cytometry A, 58, 167-176.

Menezes, J.R. \& Luskin, M.B. (1994) Expression of neuron-specific tubulin defines a novel population in the proliferative layers of the developing telencephalon. J. Neurosci., 14, 5399-5416.

Mereu, G., Fa, M., Ferraro, L., Cagiano, R., Antonelli, T., Tattoli, M., Ghiglieri, V., Tanganelli, S., Gessa, G.L. \& Cuomo, V. (2003) Prenatal exposure to a cannabinoid agonist produces memory deficits linked to dysfunction in hippocampal long-term potentiation and glutamate release. Proc. Natl. Acad. Sci. U.S.A., 100, 4915-4920. 
Molina-Holgado, F., Amaro, A., Gonzalez, M.I., Alvarez, F.J. \& Leret, M.L. (1996) Effect of maternal delta 9-tetrahydrocannabinol on developing serotonergic system. Eur. J. Pharmacol., 316, 39-42.

Morales, M., Wang, S.D., Diaz-Ruiz, O. \& Jho, D.H. (2004) Cannabinoid $\mathrm{CB} 1$ receptor and serotonin 3 receptor subunit $\mathrm{A}$ (5-HT3A) are co-expressed in GABA neurons in the rat telencephalon. J. Comp. Neurol., 468, 205-216.

Morozov, Y.M. \& Freund, T.F. (2003) Post-natal development of type cannabinoid receptor immunoreactivity in the rat hippocampus. Eur. J. Neurosci., 18, 1213-1222.

Mulder, J., Aguado, T., Keimpema, E., Barabás, K., Ballester Rosado, C.J., Nguyen, L., Monory, K., Marsicano, G., Di Marzo, V., Hurd, Y.L., Guillemot, F., Mackie, K., Lutz, B., Guzmán, M., Lu, H.C., Galve-Roperh, I \& Harkany, T. (2008) Endocannabinoid signaling controls pyramidal cell specification and long-range axon patterning. Proc. Natl. Acad. Sci. U.S.A., 105, 8760-8765.

Rakic, P. (2006) A century of progress in corticoneurogenesis: from silver impregnation to genetic engineering. Cereb. Cortex, 16(Suppl. 1), i3-i17.

Rodriguez de Fonseca, F., Cebeira, M., Fernandez-Ruiz, J.J., Navarro, M. \& Ramos, J.A. (1991) Effects of pre- and perinatal exposure to hashish extracts on the ontogeny of brain dopaminergic neurons. Neuroscience, $\mathbf{4 3}$ 713-723.

Super, H., Soriano, E. \& Uylings, H.B. (1998) The functions of the preplate in development and evolution of the neocortex and hippocampus. Brain Res. Brain Res. Rev., 27, 40-64.

Tappe-Theodor, A., Agarwal, N., Katona, I., Rubino, T., Martini, L., Swiercz, J., Mackie, K., Monyer, H., Parolaro, D., Whistler, J., Kuner, T. \& Kuner, R. (2007) A molecular basis of analgesic tolerance to cannabinoids J. Neurosci., 27, 4165-4177.

Turu, G., Simon, A., Gyombolai, P., Szidonya, L., Bagdy, G., Lenkei, Z. \& Hunyady, L. (2007) The role of diacylglycerol lipase in constitutive and angiotensin AT1 receptor-stimulated cannabinoid CB1 receptor activity. J. Biol. Chem., 282, 7753-7757.

Vela, G., Martin, S., Garcia-Gil, L., Crespo, J.A., Ruiz-Gayo, M., FernandezRuiz, J.J., Garcia-Lecumberri, C., Pelaprat, D., Fuentes, J.A., Ramos, J.A. \& Ambrosio, E. (1998) Maternal exposure to delta9-tetrahydrocannabinol facilitates morphine self-administration behavior and changes regional binding to central mu opioid receptors in adult offspring female rats. Brain Res., 807, 101-109.

Vitalis, T., Berger, B., Rossier, J. \& Lenkei, Z. (2004) Transient Expression of the CB1 Cannabinoid Receptor in Projection Neurons of the Embryonic Brain 2004 Abstract Viewer/Itinerary Planner. Society for Neuroscience, Washington, DC, Online.

Walters, D.E. \& Carr, L.A. (1986) Changes in brain catecholamine mechanisms following perinatal exposure to marihuana. Pharmacol. Biochem. Behav., 25, 763-768.

Walters, D.E. \& Carr, L.A. (1988) Perinatal exposure to cannabinoids alters neurochemical development in rat brain. Pharmacol. Biochem. Behav, 29, 213-216.

Watson, S., Chambers, D., Hobbs, C., Doherty, P. \& Graham, A. (2008) The endocannabinoid receptor, $\mathrm{CB} 1$, is required for normal axonal growth and fasciculation. Mol. Cell. Neurosci., 38, 89-97.

Williams, E.J., Walsh, F.S. \& Doherty, P. (2003) The FGF receptor uses the endocannabinoid signaling system to couple to an axonal growth response. J. Cell Biol., 160, 481-486.

Wu, D.F., Yang, L.Q., Goschke, A., Stumm, R., Brandenburg, L.O., Liang, Y.J., Hollt, V. \& Koch, T. (2008) Role of receptor internalization in the agonistinduced desensitization of cannabinoid type 1 receptors. J. Neurochem., 104, 1132-1143.

Yap, C.C., Wisco, D., Kujala, P., Lasiecka, Z.M., Cannon, J.T., Chang, M.C., Hirling, H., Klumperman, J. \& Winckler, B. (2008) The somatodendritic endosomal regulator NEEP21 facilitates axonal targeting of L1/NgCAM. J. Cell Biol., 180, 827-842. 